\title{
Which Green Transport Corridors (GTC) Are Efficient? A Dual-Step Approach Using Network Equilibrium Model (NEM) and Data Envelopment Analysis (DEA)
}

\author{
Paulo Nocera Alves Junior 1,*®D, Isotilia Costa Melo ${ }^{2}{ }^{\mathbb{D}}$, José Eduardo Holler Branco ${ }^{1}$, \\ Daniela Bacchi Bartholomeu ${ }^{1}$ and José Vicente Caixeta-Filho ${ }^{1}$ \\ 1 Luiz de Queiroz College of Agriculture (ESALQ), University of São Paulo (USP), \\ Piracicaba 13418-900, SP, Brazil; jehbranco@usp.br (J.E.H.B.); daniela.bartholomeu@usp.br (D.B.B.); \\ jose.caixeta@usp.br (J.V.C.-F.) \\ 2 Sao Carlos School of Engineering (EESC), University of São Paulo (USP), São Carlos 13562-190, SP, Brazil; \\ isotilia@usp.br \\ * Correspondence: pnalvesjr@usp.br
}

check for updates

Citation: Alves Junior, P.N.; Melo, I.C.; Branco, J.E.H.; Bartholomeu, D.B.; Caixeta-Filho, J.V. Which Green Transport Corridors (GTC) Are Efficient? A Dual-Step Approach Using Network Equilibrium Model (NEM) and Data Envelopment Analysis (DEA). J. Mar. Sci. Eng. 2021, 9, 247. https://doi.org/10.3390/ jmse9030247

Academic Editor: Okan Duru, Chris Clott, Bruce Hartma and Sinem Celik Girgin

Received: 22 December 2020

Accepted: 21 February 2021

Published: 26 February 2021

Publisher's Note: MDPI stays neutral with regard to jurisdictional claims in published maps and institutional affiliations.

Copyright: (c) 2021 by the authors. Licensee MDPI, Basel, Switzerland. This article is an open access article distributed under the terms and conditions of the Creative Commons Attribution (CC BY) license (https:/ / creativecommons.org/licenses/by/ $4.0 /)$.
Abstract: The development of Green Transport Corridors (GTCs) is an important strategy to help a region achieve more sustainable solutions. When such GTCs are implemented, multimodal supply chains and environmentally-friendly alternatives for freight transportation through economically relevant hubs and long-distance routes can be facilitated. Based on previous efforts for evaluating single routes, this paper aimed to propose a single multi-criteria Logistics Composite Index (LCI), constructed based on a set of Key Performance Indicators (KPIs), to evaluate the efficiency of GTCs considering the integration of multiple transport modes (highways, railways, and waterways). This approach consists of a dual-step procedure, applying a Network Equilibrium Model (NEM) and Data Envelopment Analysis (DEA). It was applied to Brazilian agricultural bulk transport export corridors, considering the existing and planned infrastructure in the harvest year of 2018/2019. In general, the best indexes were those from corridors considering planned railways. Specifically, the best index was from a corridor from the Northeast region. The second was from the South. The third was from the North (Amazon), and was one of the few corridors with adequate waterways. This approach is useful for decision-makers to determine the most efficient corridors as well as for policy-makers to guide infrastructure investments and address public policies.

Keywords: Green Transport Corridor (GTC); Freight Transportation; Network Equilibrium Model (NEM); Data Envelopment Analysis (DEA); Key Performance Indicator (KPI); Logistics Composite Index (LCI)

\section{Introduction}

Green Transport Corridors (GTCs) are integrated, efficient, and environmental-friendly freight transportation through economically relevant hubs and long-distance routes [1]. The development of GTCs is an important strategy for a region to achieve more sustainable solutions and more integrated multimodal supply chains [2]. The challenge is to define and to measure representative performance indicators of GTCs [3].

One way of simultaneously evaluating the many aspects-financial, environmental, or/and social — of transportation is through Key Performance Indicators (KPI), specifically constructing a Logistics Performance Index (LPI). The global well-known LPI elaborated by the World Bank measures a country-level performance based on six aspects: customs, infrastructure, international shipment, logistics quality and competence, tracking and tracing, and timeliness [4]. However, it does not represent in-country transportation routes or regional specifications.

On the other hand, customized regional logistics KPIs diverge depending on each corridor management interest selection, hindering the relative comparison among different 
corridors in a wider territorial region such as country [5]. Additionally, the standardized regional KPIs (incorporating sustainability) are helpful for planning, monitoring, and managing GTCs, regarding operational, enabling eco-efficiency, and risk aspects [2,6,7].

In this regard, two previous and independent efforts applied Data Envelopment Analysis (DEA) to construct a logistics index for evaluating soybeans export routes in Brazil. One paper focused on the three pillars of sustainability for measuring the efficiency of the most important soybean exporting routes, compared to American exporting routes [3], and the other paper focused on investigating the impacts of the construction of a new waterway to the existent Brazilian exporting routes [8]. It is important to point out that both papers measured the performance of single routes. They did not assess the total Transport Corridors' performance in a holistic approach. In addition, the measurement was based on the aspects of routes' origins, transport infrastructure, and quantities of soybean moved, and not based on the targets of the transportation (i.e., the destination ports).

This paper aims to propose a single multi-criteria Logistics Composite Index (LCI) constructed using the set of KPIs to evaluate the efficiency of GTCs used to export solid agricultural bulk (soybeans and corn). This KPI focuses on the destination export ports and consists of a dual-step procedure jointly applying the Network Equilibrium Model (NEM) and Data Envelopment Analysis (DEA). Along these lines, this paper aims to propose an innovative multi-criteria logistics composite index integrating a set of KPIs.

This proposition of a dual-step procedure applying NEM and DEA for measuring the relative transportation efficiency (the LCI) is a methodological novelty in the literature. The proposition of measuring whole GTCs' performance (instead of the individual routes' performance) also represents a practical innovative holistic approach, more integrated into real life. Finally, it is worth noting that the proposition of simultaneously measuring corridors that may encompass three cargo transport modes (road, water, and rail) as well as the impact of planned infrastructure projects in a developing country is also new in the literature due to its wide and impacting scope of integration.

The application measured the efficiency of the transportation corridors used to export soybean and corn in Brazil in the harvest year of 2018/2019, which accounts for the largest fraction of the agricultural commodities exports of the country. The LCI can be used to guide future investments in infrastructure and to address policies and actions to develop GTCs. The methodology is also useful and replicable for different contexts, countries, and cargos.

The paper is structured into five sections. The Introduction presents the background of KPIs for agricultural product logistics, NEM, and DEA. Thereafter, the second section brings the mathematical formulation of the two proposed steps (NEM for the routes and DEA for the GTCs). The third section brings the detailed efficiency results, considering 12 corridors exclusively with the current infrastructure and 12 corridors, incorporating routes with planned railroad infrastructure integrated into the current infrastructure. The fourth section discusses the results. It is divided into three subsections, one discussing the current infrastructure, another discussing the planned projects, and the third one discussing the practical implications. Finally, the fifth section summarizes the main findings and their implications for decision- and policy-makers, replicability of the approach for other contexts, and future research directions.

\section{Literature Review}

In 1952, Wardrop [9] formalized the notions and principles used in equilibrium models to minimize total travel costs [10]. These models are classified into Spatial Price Equilibrium (SPE) model or NEM. The main difference between SPE and NEM is that an SPE model considers price-dependent supply and demand, while NEM considers them as exogenous variables [11]. The NEM allows the formulation of linear programming (LP) model structure that guarantees a global maximum or minimum solution to find the lowest cost without the necessity of estimating price-dependent supply and demand functions [12]. 
As demonstrated by Zhou et al. (2018) [13], while green logistics and transportation is a difficult problem (NP-hard), solutions via proper analytical models can be derived efficiently from problems of a practical scale. Considering the NEM literature focused on multimodal, sustainable, and green transportation, Wang et al. (2020) [14] proposed a model to evaluate a multimodal network considering captive mode travelers (those who have no other choices but rely on one specific travel mode for daily commuting trips). Some studies applied NEM for analyzing the $\mathrm{CO}_{2}$ emission and environmental impact of multimodal infrastructures in Brazilian context [12,15].

In this regard, the NEM applications in green transportation are increasing. Applications in green and sustainable cargo transportation are still rare and the current paper contributes to the construction of the body of knowledge, proposing an application for GTCs. To address other criteria in the evaluation of the transport corridors, this paper applied DEA after NEM in a dual-step procedure for evaluating the corridors' performance according to their infrastructure, flows, exports, and sustainability measures.

Based on the increasing relevance of the DEA in transportation research, Mahmoudi et al. (2020) [16] elaborated a literature review and proposed a taxonomy for DEA applications in transportation systems. According to the authors, there are six categories: highways, air, maritime, railways, green issues, and others. Within these categories, the DEA is used to evaluate decision-making units (DMUs), e.g., companies, routes, corridors, etc., or obtaining the operational, maintenance, safety, lifecycle assessment, environmental, or sustainability efficiency, e.g., of passengers or freight transportation, in urban, public, or other kinds of transportations, considering the infrastructures and green measures. The authors concluded that DEA is already accepted as a useful approach for policy-makers, though the DEA can also be helpful for decision-makers, in contexts with environmental factors, sustainable development, and eco-design [16].

Among the DEA applications to corridors and routes (regarding cargo and passenger transportations), the most relevant identified contributions were: the development of a model for efficiency assessment of key ports in the 21st-Century Maritime Silk Road economic trade corridor [17] and the development of an index for assessing the impact of new infrastructure in the high-speed train corridor [18]. Also, six assessments were identified. They evaluated European green importing routes, integrating costs, and socio-ecological factors to performance evaluation [19], the impact of the China-Pakistan economic corridor on energy consumption and saving potential [20], rail and road freight transportation network operating along corridors of countries from Europe and North America [21], the transit transport corridor in African countries [22], terminals in the Brazilian Northeastern corridor [23], and the infrastructure performance of the multimodal urban public transit system from India [24] and Chile [25].

In addition, two papers applied DEA in a more similar context to the current paper (encompassing cargo transportation and multi-criteria/sustainability efficiency). One paper applied a DEA CCR model-Constant Returns to Scale (CRS) - to create a country-level index in the EU context. And another paper applied DEA CCR models to measure the efficiency of corn haulage in selected Brazilian routes [26]. However, the assumptions for applying a DEA CCR model in this context have already been described as inadequate $[27,28]$.

Regarding the same DEA model (second step of the method proposed here) in a similar context application, there is an application of the DEA non-radial and non-oriented model, named Slack-Based Measure (SBM) [29] under a Variable Returns to Scale (VRS) assumption, for choosing alternatives of international biomass supply chain [30]. Another paper proposed a country-level logistics performance index, using SBM and Malmquist [31]. There are two applications of the SBM with the VRS assumption to create a multi-criteria logistics index, incorporating all the pillars of sustainability. Both applications evaluated different soybean transportation routes in Brazil [3,32].

According to Mahmoudi et al. (2020) [16], the effects of transportation systems in GHG emissions, climate changes, and environmental issues is a common problem in the context of DEA applied to transportation systems, but most of these papers focus on land transportation 
(railways and highways). However, recent papers showed that investment and project selection are interesting research directions. Also, the DEA can be applied to evaluate the effects of changes on the performance of transportation systems in developing countries.

In this way, the current paper contributes to overcoming a gap in the literature related to the measurement of GTCs' performance. This is because, besides applying an innovative and adequate dual-step NEM and DEA methodological approach, it identifies planned investments in new railway projects, integrating them to the multimodal corridors. This happens in the first step, through the application of the NEM model to assign the optimal transportation flows inside the corridors, and using DEA to evaluate the effect of the planned infrastructure in the GTCs, also focusing on the export ports (destination). Finally, the application in a developing country is relevant for economic development and can be replicated in other regional contexts.

\section{Materials and Methods}

Figure 1 is a flowchart of the proposed methodology (i.e., in chronological order).

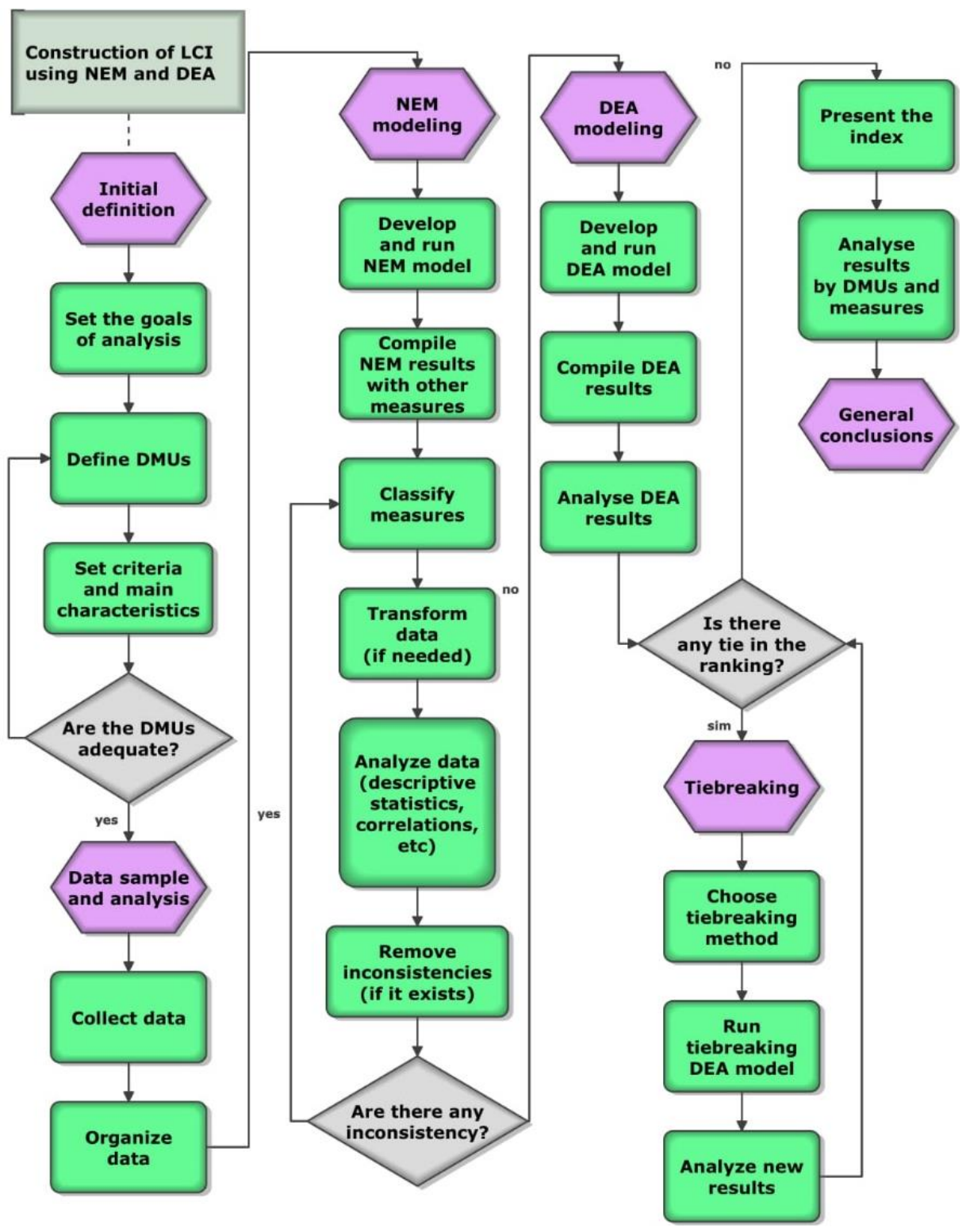

Figure 1. Flowchart of the proposed methodology. 
After finding the gap in the literature, the methodology was proposed (Figure 1). The goal was to propose a multi-criteria LCI to evaluate the efficiency of GTCs considering existing and planned infrastructure in a multimodal network. Then the initial definitions were set, defining the homogeneous DMUs (corridors as an aggregation of routes), setting criteria and main characteristics (e.g., to check if the number of DMUs is higher than three times the sum of the number of measures). The next steps are related to the data and modeling. Collecting data to use in NEM modeling (obtaining the optimal flows) and partially for DEA (the other data is from NEM results). The NEM results by routes were compiled with other previously collected data, transformed into corridors aggregating by the importance of each route (i.e., in a weighted average, the weights of the routes are proportional to the amount of cargo moved in each route of the corridor). The measures of the corridors are classified in inputs or outputs, desirables or undesirables, and data analysis was made (e.g., to check the isotonicity). Then DEA was applied with the Composite Index (CI) tiebreaking method. With these results is possible to discuss and conclude the research.

The next subsections supply the de details of the NEM model (Section 2.1), the DEA model (Section 2.2), and information about the data and the context of the application (Section 2.3).

\subsection{Formulation of Network Equilibrium Model (NEM)}

The NEM was used to assign the optimal distribution of soybean and corn production and the transportation flows between production and demand regions into the multimodal transport network, aiming at minimizing total cost and calculating the $\mathrm{CO}_{2}$ emissions generated by the transportation flows. Also, the impact of the planned railways on the transport flows was evaluated.

The model structure is similar to [12] and it is presented in Equations (1)-(6). The objective function of the model is defined by Equation (1) and it minimizes the transportation cost (C) of supplying soybean and corn to domestic demand regions and export terminals. The solution is constrained by transportation capacities, supply and demand levels, and conditions of the Brazilian soybean and corn supply chain. These constraints are presented in Equations (2)-(6).

The constraint in Equation (2) defines that the total quantity of soybeans and corn shipped to supply domestic demand and exports must be lower or equal to the production $\left(\mathrm{PRO}_{\mathrm{o}}^{\mathrm{p}}\right)$ of each product $\mathrm{p}$ in the origin region $\mathrm{o}$.

Ensuring the supply of domestic demand (c $=d m$ ), Equation (3) states the total amount of products moved to each demand region must be equal to the domestic demand $\left(\mathrm{DEM}_{\mathrm{d}}^{\mathrm{p}}\right)$ for each product in that region.

The equality constraint in Equation (4) guarantees that the total amount of each product moved to each destination node is addressed as exporting terminal $(\mathrm{d} \in\{\mathrm{sp}\})$ is equal to the international demand $(\mathrm{c}=\mathrm{im})$.

The equality constraint in Equation (5) guarantees that the transportation flows arriving in each transshipment terminal $t$ must be equal to the transportation flows that are departing from that terminal.

Equation (6) is related to the limitation of the total quantity of cargo assigned to each transshipment terminal $t$ and it must be equal to or less than the load capacity of that terminal, represented by TCAP . The complete model structure is similar to [12] and it can be seen as follows in Equations (1)-(6).

$$
\text { Min C }=\sum_{\mathrm{o}} \sum_{\mathrm{d}} \sum_{\mathrm{c}} \sum_{\mathrm{p}} \mathrm{ROD}_{\mathrm{od}}^{\mathrm{cp}} \cdot \mathrm{TC}_{\mathrm{od}}+\sum_{\mathrm{o}} \sum_{\mathrm{t}} \sum_{\mathrm{c}} \sum_{\mathrm{p}} \mathrm{ROT}_{\mathrm{ot}}^{\mathrm{cp}} \cdot \mathrm{TC}_{\mathrm{ot}}+\sum_{\mathrm{t}} \sum_{\mathrm{d}} \sum_{\mathrm{c}} \sum_{\mathrm{p}} \mathrm{MM}_{\mathrm{td}}^{\mathrm{cp}} \cdot \mathrm{TC}_{\mathrm{td}}
$$

Subject to:

$$
\begin{gathered}
\sum_{\mathrm{d}} \sum_{\mathrm{c}} \mathrm{ROD}_{\mathrm{od}}^{\mathrm{cp}}+\sum_{\mathrm{t}} \sum_{\mathrm{c}} \mathrm{ROT}_{\mathrm{ot}}^{\mathrm{cp}} \leq \mathrm{PRO}_{\mathrm{o}}^{\mathrm{p}}, \forall \mathrm{o} \text { and } \mathrm{p} \\
\sum_{\mathrm{o}} \mathrm{ROD}_{\mathrm{od}}^{\mathrm{cp}}+\sum_{\mathrm{t}} \mathrm{MM}_{\mathrm{td}}^{\mathrm{cp}}=\mathrm{DEM}_{\mathrm{d}^{\prime}}^{\mathrm{p}}, \forall \mathrm{d}, \mathrm{p} \text { and } \mathrm{c}=\mathrm{dm}
\end{gathered}
$$




$$
\begin{gathered}
\sum_{\mathrm{o}} \mathrm{ROD}_{\mathrm{od}}^{\mathrm{cp}}+\sum_{\mathrm{t}} \mathrm{MM}_{\mathrm{td}}^{\mathrm{cp}}=\mathrm{EXP}_{\mathrm{d}}^{\mathrm{p}}, \forall \mathrm{d} \in\{\mathrm{sp}\}, \mathrm{p} \text { and } \mathrm{c}=\mathrm{im} \\
\sum_{\mathrm{o}} \mathrm{ROT}_{\mathrm{ot}}^{\mathrm{cp}}=\sum_{\mathrm{d}} \mathrm{MM}_{\mathrm{td}}^{\mathrm{cp}}, \forall \mathrm{t}, \mathrm{c} \text { and } \mathrm{p} \\
\sum_{\mathrm{o}} \sum_{\mathrm{c}} \sum_{\mathrm{p}} \mathrm{ROT}_{\mathrm{ot}}^{\mathrm{cp}} \leq \mathrm{TCAP}_{\mathrm{t}}, \forall \mathrm{t}
\end{gathered}
$$

where C: Total transportation cost (US\$).; TC: Transportation cost rate (US\$/ton of cargo) from origin to destination $\left(\mathrm{TC}_{\mathrm{od}}\right)$, from origin to transshipment terminal $\left(\mathrm{TC}_{\mathrm{ot}}\right)$, and from transshipment terminal to destination $\left(\mathrm{TC}_{\mathrm{td}}\right)$; $\mathrm{ROD}_{\mathrm{od}}^{\mathrm{cp}}$ : Road transportation flow of product $p$ between origin o and destination $d$, in market $c ; R^{2} T_{\mathrm{ot}}^{\mathrm{cp}}$ : Road transportation flow of product $\mathrm{p}$ between origin o and transshipment point $\mathrm{t}$, in market $\mathrm{c} ; \mathrm{MM}_{\mathrm{td}}^{\mathrm{cp}}$ : Multimodal transportation flow of product $p$ between transshipment point $t$ and destination $d$, in market c; $\mathrm{PRO}_{\mathrm{o}}^{\mathrm{p}}$ : Production of each product $\mathrm{p}$ and origin region o; $\mathrm{DEM}_{\mathrm{d}}^{\mathrm{p}}$ : Domestic Demand of product $\mathrm{p}$ in the domestic destination $\mathrm{d}$; $\operatorname{EXP}_{\mathrm{d}}^{\mathrm{p}}$ : Exportation of product $\mathrm{p}$ in the port destination $d$; $\mathrm{TCAP}_{\mathrm{t}}$ : Total load capacity of the transshipment terminal $\mathrm{t}$; $\mathrm{dm}$ : domestic market; im: international market; sp : set of destinations classified as export terminals.

After applying the NEM model, the routes were aggregated (i.e., the routes used to move more cargo have a greater weight in a weighted average) to define the corridors and apply DEA to evaluate its performance.

\subsection{Formulation of Data Envelopment Analysis (DEA) Model}

The DEA is a non-parametric method that can be applied to measure the efficiency of Decision-Making Units (DMUs) in systems with multiple inputs and multiple outputs, and with different units of measurement. Besides, DEA can also be used for constructing a performance Composite Index (CI) in general, where the outputs are indicators to be maximized and the inputs are indicators to be minimized [33]. The formulation of the models change regarding the orientation (input, output, or non-oriented), assumptions of Variable Returns to Scale (VRS) or Constant Returns to Scale (CRS), among other characteristics [34,35].

In this paper, the DMUs are the transport corridors considered in the performance analysis, from corn- and soybean-producing regions to each export port. For measuring the performance of a set of DMUs, each DMU is normally associated with characteristics measures classified in, at least, inputs or outputs. For multi-criteria application, inputs can be understood as "the least, the best" and outputs as "the most, the best" - for the benefit of efficiency [33].

Some prerequisites are necessary for DEA modeling. According to Cooper et al. (2007) [36], considering a high number of measures in the model can diminish the discriminant level of the model, and it is possible (but it will not necessarily happen) to obtain many tied efficient DMUs, so the authors' guide is that the number of DMUs being higher than three times the sum of the number of measures. In this paper, we collected data from seven measures, from 24 DMUs, respecting this prerequisite.

According to Dyson et al. (2001) [28], another prerequisite in DEA modeling is the homogeneity of the DMUs. For example, if the DMUs are homogeneous, they make similar activities, comparable products, or services, and a common set of measures can be defined to all DMUs. In this paper, the DMUs are the corridors, from origins to export ports.

According to Golany and Roll (1989) [37], the "isotonicity" between inputs and output is assumed when using DEA. Thus, increasing input values may lead to increasing output value (but not the opposite). Their relationship was tested by applying Kendall's Tau ordinal correlation coefficient (Table 1). 
Table 1. Kendall Correlation among variables of different categories.

\begin{tabular}{cccccc}
\hline & & \multicolumn{4}{c}{ DI and UI } \\
\cline { 3 - 6 } & & DEPTH & STORAGE & PAVED & COSTS \\
\hline \multirow{2}{*}{ DO and UO } & EXPORTS & $0.4046^{* * *}$ & $0.6252^{* * *}$ & -0.0774 & 0.1093 \\
& CO $_{2}$ & $0.2618^{*}$ & 0.0036 & $-0.4155^{* * *}$ & $0.8618^{* * *}$ \\
& ACCIDENTS & -0.1130 & 0.1728 & $0.3037^{* *}$ & -0.1575 \\
\hline${ }^{*} p$-value $<0.10, * * p$-value $<0.05,{ }^{* * *} p$-value $<0.01$. & &
\end{tabular}

Observing Table 1, it is possible to verify that all inputs (DI or UI) are significate and positively correlated to at least one output (DO or UO). EXPORTS is correlated to the DEPTH and STORAGE (that possible means that the routes and corridors with more storage and have ports with deeper depths attract more cargo to export). ACCIDENTS is correlated to PAVED. This possibly means that the routes and corridors with more paved highways attract more truck flows, resulting in more accidents because highways have the highest quantities of accidents among the modes. $\mathrm{CO}_{2}$ is correlated to PAVED and COSTS. This possible means that the routes and corridors with more COSTS are possibly also the ones with higher distances, resulting in more $\mathrm{CO}_{2}$, but at the same time, the only significant and negative correlation is with paved highways, possibly because the long-distance routes and corridors use less paved highways, while the opposite is true for the short-distance ones. Thus, the other correlations are not significant, and the authors found the unique significant negative correlation justifiable.

Among the DEA models, the SBM (a model previously applied for agricultural and logistic problems [3]) simultaneously minimizes inputs and maximizes outputs without requiring the selection of orientation, resulting directly in a rank of DMUs based on their efficiencies [29]. Subsequently, the CI tiebreaking method was applied [38]. It is a doublefrontier method represented by an arithmetic average between standard and inverted efficiencies. This arithmetic average is standardized by the maximum value of the analyzed set of DMUs, resulting in the composite index.

The formulation of the SBM model [29] is as follows in Equations (7)-(11):

$$
\begin{gathered}
\text { Minimize } \tau=\mathrm{t}-\left(\frac{1}{\mathrm{~m}}\right) \sum_{\mathrm{i}=1}^{\mathrm{m}} \frac{\mathrm{S}_{\mathrm{i}}^{-}}{\mathrm{x}_{\mathrm{i} 0}} \\
\mathrm{t}+\left(\frac{1}{\mathrm{n}}\right) \sum_{\mathrm{j}=1}^{\mathrm{n}} \frac{\mathrm{S}_{\mathrm{j}}^{+}}{\mathrm{y}_{\mathrm{j} 0}}=1 \\
\sum_{\mathrm{k}=1}^{\mathrm{z}} \Lambda_{\mathrm{k}} \mathrm{x}_{\mathrm{jk}}+\mathrm{S}_{\mathrm{i}}^{-}-\mathrm{t} \cdot \mathrm{x}_{\mathrm{i} 0}=0 \quad \mathrm{i}=1,2, \ldots, \mathrm{m} \\
\sum_{\mathrm{k}=1}^{\mathrm{z}} \Lambda_{\mathrm{k}} \mathrm{y}_{\mathrm{jk}}-\mathrm{S}_{\mathrm{j}}^{+}-\mathrm{t} \cdot \mathrm{y}_{\mathrm{j} 0}=0 \quad \mathrm{j}=1,2, \ldots, \mathrm{n} \\
\Lambda_{\mathrm{k}} \geq 0, \mathrm{~S}_{\mathrm{i}}^{-} \geq 0, \mathrm{~S}_{\mathrm{j}}^{+} \geq 0 \text { and } \mathrm{t}>0
\end{gathered}
$$

where $\tau$ : Efficiency, $t$ : Model linearization variable, $S_{i}^{-}$: Slack of the ith input, $S_{j}^{+}$: Slack of the jth output, $\Lambda_{\mathrm{k}}$ : Contribution of the kth DMU to the analyzed DMU, $\mathrm{x}_{\mathrm{i} 0}$ : ith input of the DMU under analysis, $\mathrm{y}_{\mathrm{j} 0}$ : jth output of the DMU under analysis, $\mathrm{x}_{\mathrm{jk}}$ : ith input of the kth DMU, $y_{j k}$ : jth output of the kth DMU, m: Number of inputs, n: Number of outputs, $z$ : Number of DMUs.

The standard models are formulated considering desirable outputs $(\mathrm{O})$ (to be maximized), and desirable inputs (I) (to be minimized), but in real situations, there are undesirable outputs (UO) (to be minimized) and undesirable inputs (UI) (to be maximized) [39]. The simplest approaches to deal with UO and UI are based on treating UO as an output with negative effect (i.e., mathematically it is an output behaving as an input, so, in a post-efficiency analysis, the goal is to decrease the UO) and UI as an input with positive 
effect (i.e., mathematically it is an input behaving as an output, so, in a post-efficiency analysis, the goal is to increase the UI), or by data-transformation, but this second approach can lead to adverse results [39].

The Slack-Based Measure also allows the Variable Returns to Scale (VRS) or Constant Returns to Scale (CRS) assumption [29]. According to Cook et al. (2014) [33], mixing raw data with ratios is permissible in DEA, but the VRS assumption is preferable, mainly when the ratio data is in percentages because considering CRS assumption not always maintain the projection between $0 \%$ and $100 \%$. The model from this paper is under the VRS assumption, considering the incorporation of UO and UI [39] and the VRS assumption. The model is formulated as follows in Equations (12)-(19) [39]:

$$
\begin{aligned}
& \text { Minimize } \tau=\mathrm{t}-\left(\frac{1}{\mathrm{~m}+\mathrm{n}^{\mathrm{U}}}\right)\left(\sum_{\mathrm{i}=1}^{\mathrm{m}} \frac{\mathrm{S}_{\mathrm{i}}^{-}}{\mathrm{x}_{\mathrm{i} 0}}+\sum_{\mathrm{j}^{\mathrm{U}}=1}^{\mathrm{n}^{\mathrm{U}}} \frac{\mathrm{S}_{\mathrm{j}}^{\mathrm{U}} \mathrm{y}_{\mathrm{j}^{\mathrm{U}}}^{\mathrm{U}}}{\mathrm{U}^{\mathrm{U}}}\right) \\
& \mathrm{t}+\left(\frac{1}{\mathrm{n}+\mathrm{m}^{\mathrm{U}}}\right)\left(\sum_{j=1}^{\mathrm{n}} \frac{\mathrm{S}_{\mathrm{j}}^{+}}{\mathrm{y}_{\mathrm{j} 0}}+\sum_{\mathrm{i}^{\mathrm{U}}=1}^{\mathrm{m}^{\mathrm{U}}} \frac{\mathrm{S}_{\mathrm{i}}^{\mathrm{U}} \mathrm{x}_{\mathrm{i}}^{\mathrm{U}}}{\mathrm{x}_{0}^{\mathrm{U}}}\right)=1 \\
& \sum_{k=1}^{\mathrm{z}} \Lambda_{\mathrm{k}} \mathrm{x}_{\mathrm{jk}}+\mathrm{S}_{\mathrm{i}}^{-}-\mathrm{t} \cdot \mathrm{x}_{\mathrm{i} 0}=0 \quad \mathrm{i}=1,2, \ldots, \mathrm{m} \\
& \sum_{k=1}^{z} \Lambda_{k} y_{j k}-S_{j}^{+}-t \cdot y_{j 0}=0 \quad j=1,2, \ldots, n \\
& \sum_{\mathrm{k}=1}^{\mathrm{z}} \Lambda_{\mathrm{k}} \mathrm{y}_{\mathrm{j}}^{\mathrm{U}} \mathrm{u}_{\mathrm{k}}+\mathrm{S}_{\mathrm{j}^{\mathrm{U}}}^{\mathrm{U}+}-\mathrm{t} \cdot \mathrm{y}_{\mathrm{j}^{\mathrm{U}}}^{\mathrm{U}}=0 \quad \mathrm{j}^{\mathrm{U}}=1,2, \ldots, \mathrm{n}^{\mathrm{U}} \\
& \sum_{\mathrm{k}=1}^{\mathrm{z}} \Lambda_{\mathrm{k}} \mathrm{x}_{\mathrm{i}}^{\mathrm{U}} \mathrm{U}_{\mathrm{k}}-\mathrm{S}_{\mathrm{i}^{\mathrm{U}}}^{\mathrm{U}-}-\mathrm{t} \cdot \mathrm{x}_{\mathrm{i}}^{\mathrm{U}} \mathrm{U}_{0}=0 \quad \mathrm{i}^{\mathrm{U}}=1,2, \ldots, \mathrm{m}^{\mathrm{U}} \\
& \sum_{\mathrm{k}=1}^{\mathrm{z}} \Lambda_{\mathrm{k}}-\mathrm{t}=0 \\
& \Lambda_{\mathrm{k}} \geq 0, \mathrm{~S}_{\mathrm{i}}^{-} \geq 0, \mathrm{~S}_{\mathrm{j}}^{+} \geq 0, \mathrm{~S}_{\mathrm{i}^{\mathrm{U}}}^{\mathrm{U}-} \geq 0, \mathrm{~S}_{\mathrm{j}^{\mathrm{U}}}^{\mathrm{U}} \geq 0 \text {, and } \mathrm{t}>0
\end{aligned}
$$

where $\tau$ : Efficiency, t: Model linearization variable, $\mathrm{S}_{\mathrm{i}}^{-}$: Slack of the ith input, $\mathrm{S}_{\mathrm{i}^{\mathrm{U}}}^{\mathrm{U}-}$ : Slack of the $\mathrm{i}^{\mathrm{U}}$-th UI, $\mathrm{S}_{\mathrm{j}}^{+}$: Slack of the jth output, $\mathrm{S}_{\mathrm{j}}^{\mathrm{U}}+$ : Slack of the $\mathrm{j}^{\mathrm{U}}$-th $\mathrm{UO}, \Lambda_{\mathrm{k}}$ : Contribution of the kth DMU to the analyzed DMU, $\mathrm{x}_{\mathrm{i} 0}$ : ith input of the DMU under analysis, $\mathrm{y}_{\mathrm{j} 0}$ : $\mathrm{jth}$ output of the DMU under analysis, $x_{i k}$ : ith input of the kth DMU, $y_{i k}:$ jth output of the kth DMU, $x_{i}^{U} \mathrm{U}_{k}$ : the $\mathrm{i}^{\mathrm{U}}$-th UI of the kth DMU, $\mathrm{y}_{\mathrm{j}^{\mathrm{U}}}^{\mathrm{U}}$ : the $\mathrm{j}^{\mathrm{U}}$-th UO of the kth DMU, m: Number of inputs, $\mathrm{m}^{\mathrm{U}}$ : Number of UI, $\mathrm{n}$ : Number of outputs, $\mathrm{n}^{\mathrm{U}}$ : Number of $\mathrm{UO}$, and $\mathrm{z}$ : Number of DMUs. A DMU will be deemed as efficient when $\tau^{*}=1$.

Also, the CI tiebreaking method was applied [38], according to Equation (20).

$$
\tau_{\mathrm{k}}^{\text {composite }}=\frac{\left[\tau_{\mathrm{k}}^{\text {standard }}+\left(1-\tau_{\mathrm{k}}^{\text {inverted }}\right)\right] / 2}{\left.\max \left\{\left[\tau_{\mathrm{k}}^{\text {standard }}+\left(1-\tau_{\mathrm{k}}^{\text {inverted }}\right)\right] / 2\right]\right\}} \mathrm{k}=1,2,3, \ldots, \mathrm{z}
$$

where $\tau_{\mathrm{k}}^{\text {standard: }}$ Standard efficiency of the kth DMU, $\tau_{\mathrm{k}}^{\text {inverted: }}$ : Inverted efficiency of the kth DMU (i.e., the efficiency handling inputs as outputs and vice-versa).

The ranking resulting from this modeling in Equation (20) was the final ranking used to evaluate the GTCs (further explanations in the results section). 


\subsection{Data Sample and Empirical Application}

The NEM modeling considered two kinds of transportation flows. One was composed of only highways from the origins directly to the ports (deemed "road routes"), and the other one was composed of highways from the origins to transshipment terminals, and continuing from railways or waterways terminals to the ports (deemed "multimodal route"). The current application considered two scenarios of the Brazilian transport infrastructure: Scenario 1) Only the current network of roadways, railways, waterways, and export ports; Scenario 2). The previous scenario plus the planned railways. The interregional transportation flows resultant from the modeling were aggregated into 12 export corridors (according to the export ports).

Each corridor is an aggregate of routes, from diverse corn- and soybean-producing regions (origins) to each port (destination). For example, suppose only five routes were analyzed. Three of the routes had their origins in different grain-producing locations from the Center-West region and they exported to the same port from the Northeast region. So, they would be aggregated by their importance (i.e., the routes used to move more cargo have a greater weight in a weighted average), creating the corridor from the Northern arc of the country. In parallel, suppose the other two routes had their origins in different grainproducing locations from the Southeast region, and they both exported to the same port from the Southern region. In this way, they would also be aggregated (i.e., the routes used to move more cargo have a greater weight in a weighted average), creating the corridor from the Southern arc of the country.

In practice, the DEA was applied jointly to a sample with all corridors, for comparing 24 corridors (12 corridors from each scenario) and measuring the performance of these corridors. The maps in Figures 2-4 show the multimodal transport network in the main soybean export corridors.

The 12 export ports (Figure 2) of the transport corridors are: Itacoatiara (AM), Santarém (PA), Belém/Barcarena (PA), São Luís (MA), Vitória (ES), Santos (SP), Paranaguá (PR), São Francisco do Sul (SC), Rio Grande (RS), Fortaleza (CE), Salvador (BA), and Ilhéus (BA).

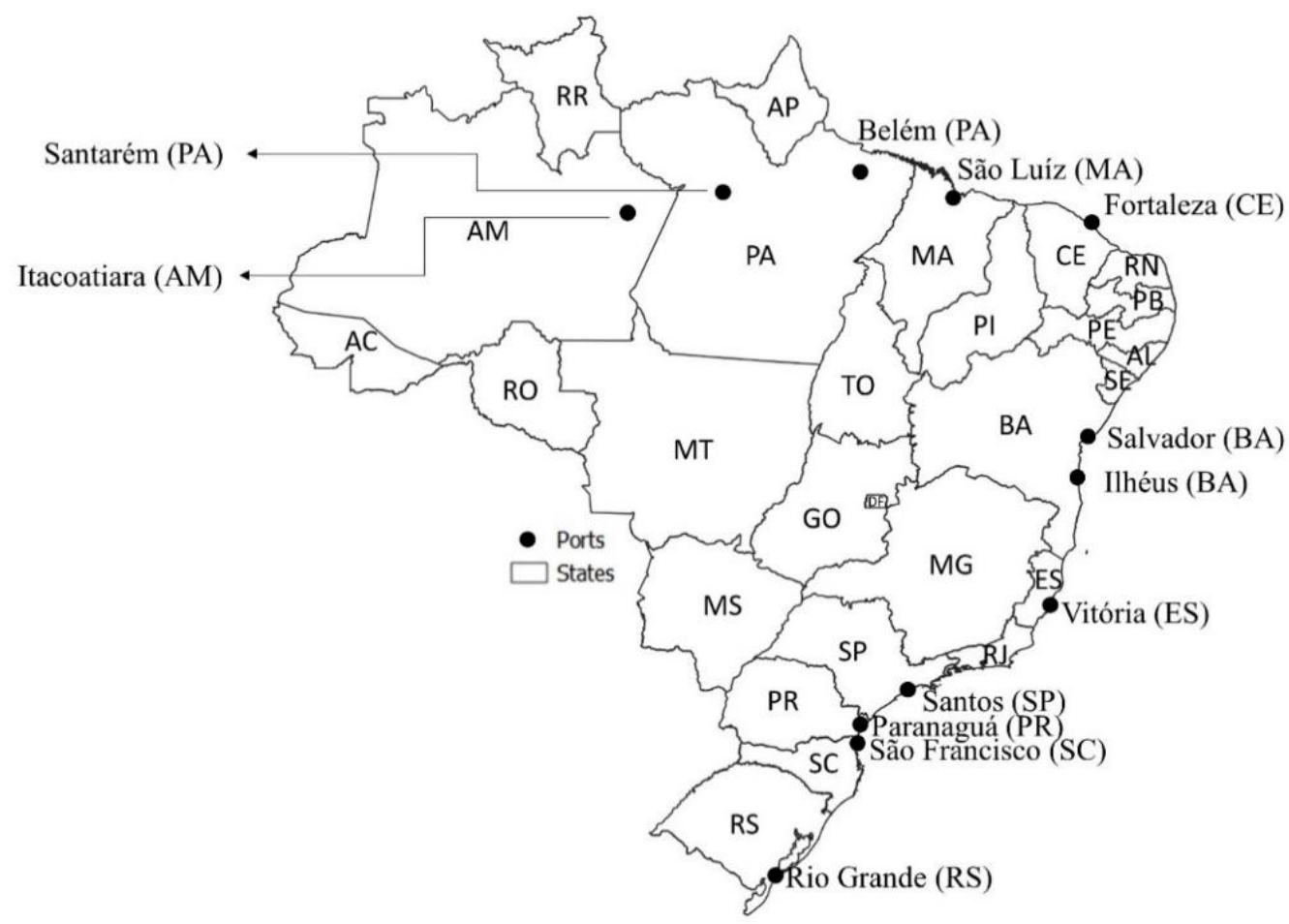

Figure 2. Export Ports and the Brazilian States. Source: Elaborated by the authors based on official sources $[40,41]$. 
The main current railways considered in Scenario 1 (Figure 3) are: Rumo (Malhas Oeste, Sul, and Paulista), Rumo Malha Norte (not entirely finished yet), Estrada de Ferro Paraná-Oeste, Ferrovia Tereza Cristina, Estrada de Ferro Carajás, Ferrovia Transnordestina, Ferrovia Centro-Atlântica, Estrada de Ferro Vitória-Minas, MRS, and Ferrovia Norte Sul (not entirely finished yet) [42].

The planned railways (for 2025 according to Planning and Logistics Company [41]) considered in scenario 2 (Figure 3 ) have received positive attention from the Brazilian government and private agents [40-42] and are listed below.

(1) Ferrograo (FG): this railway will connect Lucas do Rio Verde (MT) to Miritituba (PA) providing access to the Tapajós waterway which offers a barge transport alternative, currently in operation for exports through Port of Santarém (PA). The budget for this project predicts that investments of US\$13,290 billion are needed for the construction of $933 \mathrm{~km}$ of the railway.

(2) Ferrovia Norte-Sul (FNS): this railway will connect Palmas (TO) to Estrela D'Oeste (SP) and will provide rail access to both Port of Santos (SP) and Port of São Luís (MA). The project's budget predicts an amount of US\$2772 billion that will be needed for the implantation of $1534 \mathrm{~km}$.

(3) Ferrovia de Integração Oeste-Leste (FIOL): this railway will connect the Bahia West region to Port of Ilhéus (BA). The construction of $1022 \mathrm{~km}$ of the railway will request investments totaling US\$1650 billion.

(4) Ferrovia Rumo Malha-Norte (RMN): this project aims to extend the Railway Rumo Malha-Norte from Rondonópolis (MT) to Cuiabá (MT) and this railway provides access to Port of Santos (SP).

(5) Ferrovia Nova Transnordestina (NTN): this project will connect Eliseu Martins (PI) to Port of Pecém (RE) and Port of Suape (CE). The latest estimative is a total of US\$1740 billion for the construction of $1753 \mathrm{~km}$.

Finally, the main waterways (Figure 3) of the transport corridors are Madeira River, Amazon River, and Tapajós River in the states of the Center and North regions of the country, and the Waterway of the Tietê-Paraná River in the Center and South regions of Brazil. At last, the main Brazilian states and federal highways of the transport corridors are shown in Figure 4.

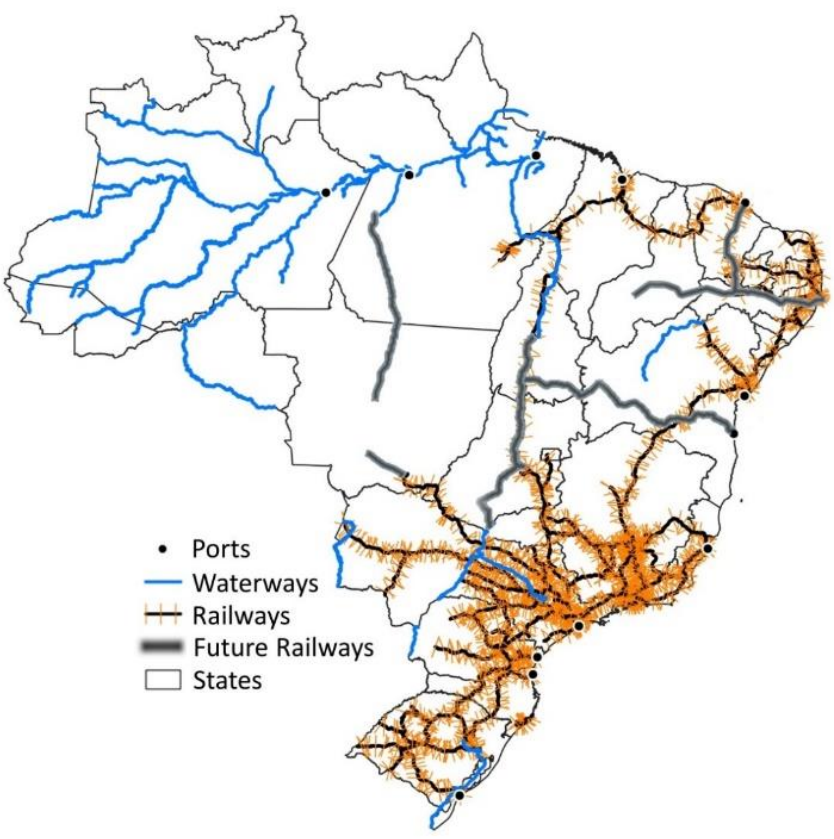

Figure 3. Brazilian Waterways, Export Ports, Current and Planned Railways. Source: Elaborated by the authors based on official sources [40-42]. 


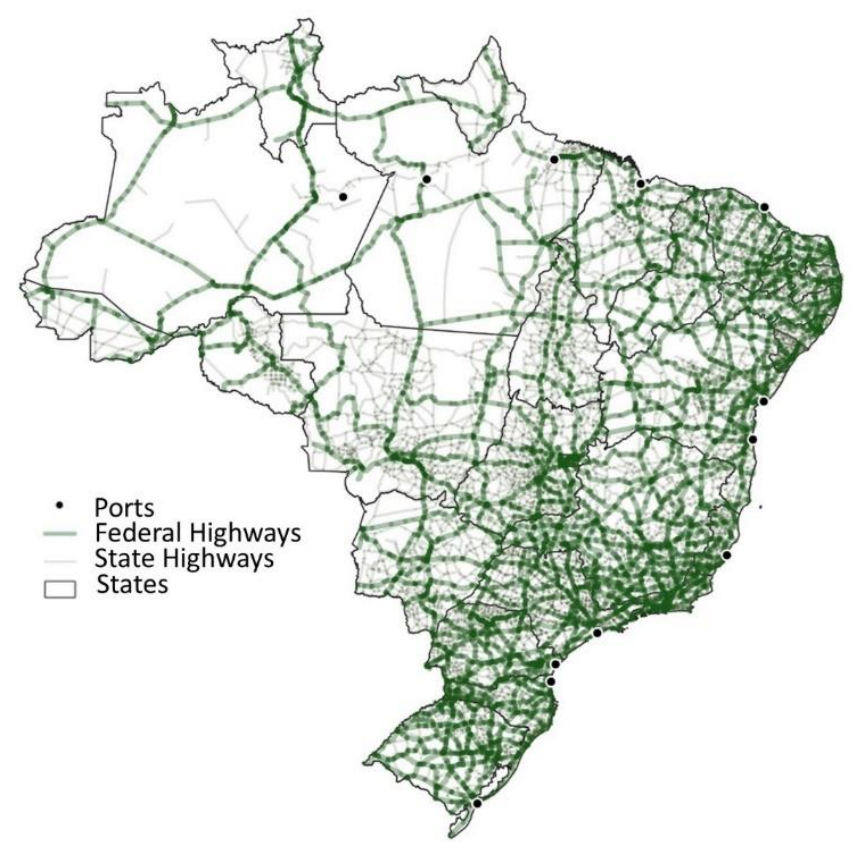

Figure 4. Export Ports and Brazilian Highways. Source: Elaborated by the authors base on official sources $[40,41]$.

In the current DEA modeling, seven measures (Tables 2 and 3) were considered and treated as follows:

- $\quad$ Output $(\mathrm{O})$ : the amount of exported soybeans and corn by each port $\left(10^{3}\right.$ tons) (EXPORTS). The EXPORTS were collected in SECEX-SISCOMEX [43]. The total sum of exports was about 107 million tons of grains, and the exports per kind of product considered in this research were about 83.5 million tons of soybean and 23.5 million tons of corn [43].

- $\quad$ Undesirable Inputs (UI): the highest draft depth of each port (meters) (DEPTH), the grain storage capacity in the catchment area ( $10^{3}$ tons) (STORAGE), and the paved road density $\left(10^{2} \mathrm{~km}\right.$ of road $/ \mathrm{km}^{2}$ of the area) of the export port catchment area (PAVED). The DEPTHs were collected in the National Waterway Transport Agency (Antaq) [44], the STORAGEs, in the Brazilian Institute of Geography and Statistics (IBGE) [45]. The PAVED highways were collected in the National Land Transportation Agency (ANTT) [46] and the National Department of Transport Infrastructure (DNIT) [47].

- $\quad$ Input (I): the weighted average freight cost of the flows arriving in each export port (BRL/ton) (COSTS). The COSTS were obtained in the database from the ESALQ-LOG group, the official Brazilian institution for agriculture logistics data [48].

- $\quad$ Undesirable Outputs (UO): the weighted average $\mathrm{CO}_{2}$ emission ( $\mathrm{kg}$ of $\mathrm{CO}_{2} /$ ton $)\left(\mathrm{CO}_{2}\right)$ and the number of accidents per kilometers estimated in the transportation corridor (accidents/km) (ACCIDENTS) [49-51].

It is worth noting that the $\mathrm{CO}_{2}$ emission is a common measure for modeling environmental aspects in this context and it was computed based on the results from NEM (distances, fuel consumption, and the amount of $\mathrm{CO}_{2}$ emitted by the fuel consumed) [3,31]. The distances were obtained in the software Transcad. The diesel consumption by road transport mode was $14.2 \mathrm{~L}$ per $10^{3}$ ton. $\mathrm{km}$, obtained in the database from the ESALQ-LOG group [48], and by water transport mode was $5 \mathrm{~L}$ per $10^{3}$ ton.km, obtained in the document about the Tietê-Paraná Waterway from Antaq [52]. The $\mathrm{CO}_{2}$ emission coefficients by rail transport mode was $0.021 \mathrm{~kg} \mathrm{CO} / \mathrm{km} \mathrm{[53],} \mathrm{by} \mathrm{water} \mathrm{transport} \mathrm{mode} \mathrm{were} 2.591 \mathrm{~kg}$ $\mathrm{CO}_{2} /$ liter of diesel and $0.013 \mathrm{~kg} \mathrm{CO} / \mathrm{km}$, and by road mode were $2.591 \mathrm{~kg} \mathrm{CO}_{2} /$ liter of diesel and $0.037 \mathrm{~kg} \mathrm{CO} / 2 \mathrm{~km} \mathrm{[12].}$ 
The social aspect of accidents is more rarely used due to, among other factors, the scarcity of data [3]. The ACCIDENTS were estimated based on highways, railways, and waterways accidents and the total distances. The accidents from highways were collected in National Transportation Confederation [49]. The accidents from railways were computed based on the accidents per train.km, on the movement of trains in rail freight transportation in train. $\mathrm{km}$, and on the distance in $\mathrm{km}$. The data was collected from the Land National Transportation Agency-ANTT [50]. Thirdly, the accidents in waterways were estimated based on the last year of the study in Naval War School and EZUTE [51].

Table 2 summarizes the variables, their DEA classifications, descriptions, and sources.

Table 2. Variables used in the Data Envelopment Analysis (DEA) model.

\begin{tabular}{|c|c|c|c|}
\hline Variable & Classification & Description & Source \\
\hline EXPORTS & $\mathrm{O}$ & The amount of exported soybeans and corn by each port ( $10^{3}$ tons) & [43] \\
\hline $\mathrm{CO}_{2}$ & $\mathrm{UO}$ & The weighted average $\mathrm{CO}_{2}$ emission $\left(\mathrm{kg}\right.$ of $\mathrm{CO}_{2} /$ ton) & Calculated based on $[3,12]$ \\
\hline ACCIDENTS & $\mathrm{UO}$ & $\begin{array}{l}\text { The number of accidents per kilometer estimated in the transportation } \\
\text { corridor (accidents } / \mathrm{km} \text { ) }\end{array}$ & Calculated based on [49-51] \\
\hline DEPTH & UI & The highest draft depth of each port (meters) & [44] \\
\hline STORAGE & UI & The grain storage capacity in the catchment area $\left(10^{3}\right.$ ton $)$ & [45] \\
\hline PAVED & UI & The paved road density $\left(10^{2} \mathrm{~km}\right.$ of road $/ \mathrm{km} 2$ of the area) & {$[46,47]$} \\
\hline COSTS & I & $\begin{array}{l}\text { The weighted average freight cost of the flows arriving in each export port } \\
\text { (BRL/ton) }\end{array}$ & [48] \\
\hline
\end{tabular}

Following the recommended approach from previous authors $[31,39,54]$ and Equations (12)-(19), the UIs were inserted in the model as Os to be maximized and the UOs, as Is to be minimized.

The aggregation of routes was calculated as a weighted average value for the corridor (or summing in the case of EXPORTS). The data is presented in Table 3. It is worth noting that the data refers to the harvest year of 2018/2019.

Table 3. Measures of the corridors used in the DEA application.

\begin{tabular}{|c|c|c|c|c|c|c|c|c|c|}
\hline & & & EXPORTS & DEPTH & STORAGE & PAVED & costs & $\mathrm{CO}_{2}$ & ACCIDENTS \\
\hline & $\begin{array}{l}\text { Destination } \\
\text { (Ports) }\end{array}$ & DMU & O1 & UI1 & UI2 & UI3 & I1 & UO1 & UO2 \\
\hline \multirow{12}{*}{$\begin{array}{c}\text { Current } \\
\text { Infrastructure }\end{array}$} & $\begin{array}{l}\text { São Francisco do } \\
\text { Sul (SC) }\end{array}$ & 1 & 4422.163 & 14 & 861.114 & 2.23 & 85.98 & 15.651 & 59.9 \\
\hline & Belém (PA) & 2 & 3482.021 & 10 & 1184.107 & 0.363 & 164.71 & 38.256 & 7.2 \\
\hline & São Luís (MA) & 3 & 8289.66 & 18 & 513.58 & 0.772 & 141.18 & 25.176 & 4.439 \\
\hline & Santos (SP) & 4 & $30,127.425$ & 14.5 & 1570.744 & 0.732 & 144.62 & 33.334 & 22.264 \\
\hline & Santarém (PA) & 5 & $23,295.56$ & 22 & 2257.627 & 0.441 & 200.98 & 47.472 & 6.777 \\
\hline & Paranaguá (PR) & 6 & $17,053.127$ & 12.7 & 1328.352 & 1.707 & 105.22 & 19.619 & 25.091 \\
\hline & Rio Grande (RS) & 7 & $13,065.192$ & 12.8 & 1872.677 & 1.997 & 82.04 & 15.064 & 11.72 \\
\hline & Itacoatiara (AM) & 8 & 2222.933 & 45 & 564.162 & 0.709 & 172.63 & 41.876 & 1.333 \\
\hline & Vitória (ES) & 9 & 1062.496 & 10.7 & 826.429 & 1.393 & 142.45 & 27.877 & 14.59 \\
\hline & Ilhéus (BA) & 10 & 957.503 & 9.3 & 265.68 & 1.116 & 133.35 & 29.251 & 13.9 \\
\hline & Fortaleza (CE) & 11 & 2.73 & 10 & 3.2 & 1.106 & 83.13 & 14.832 & 14 \\
\hline & Salvador (BA) & 12 & 3189.217 & 8 & 237.3 & 1.102 & 143.58 & 32.19 & 13.9 \\
\hline \multirow{12}{*}{$\begin{array}{l}\text { Infrastructure } \\
\text { with planned } \\
\text { railways }\end{array}$} & $\begin{array}{l}\text { São Francisco do } \\
\text { Sul (SC) }\end{array}$ & 13 & 4422.163 & 14 & 861.114 & 2.23 & 85.98 & 15.651 & 59.9 \\
\hline & Belém (PA) & 14 & 1403.435 & 10 & 92.887 & 0.298 & 76.02 & 12.79 & 7.2 \\
\hline & São Luís (MA) & 15 & 7584.268 & 18 & 501.253 & 0.758 & 129.69 & 21.634 & 3.606 \\
\hline & Santos (SP) & 16 & $22,117.139$ & 14.5 & 1074.641 & 0.939 & 111.44 & 22.256 & 17.065 \\
\hline & Santarém (PA) & 17 & $36,921.743$ & 22 & 2277.599 & 0.443 & 107.67 & 28.269 & 2.618 \\
\hline & Paranaguá (PR) & 18 & $15,611.519$ & 12.7 & 1399.191 & 1.767 & 95.34 & 16.892 & 16.643 \\
\hline & Rio Grande (RS) & 19 & $13,065.192$ & 12.8 & 1872.677 & 1.997 & 74.81 & 12.88 & 6.398 \\
\hline & Itacoatiara (AM) & 20 & 1226.66 & 45 & 16.617 & 0.792 & 151.64 & 36.36 & 2.338 \\
\hline & Vitória (ES) & 21 & 130.468 & 10.7 & 826.416 & 1.393 & 110.06 & 18.834 & 6.079 \\
\hline & Ilhéus (BA) & 22 & 4146.667 & 9.3 & 243.853 & 1.106 & 104.37 & 19.178 & 0.409 \\
\hline & Fortaleza (CE) & 23 & 540.72 & 10 & 3.2 & 1.106 & 126.73 & 38.074 & 1.931 \\
\hline & Salvador (BA) & 24 & 0.053 & 8 & 237.307 & 1.102 & 46.63 & 4.353 & 13.9 \\
\hline
\end{tabular}




\section{Results}

From the application of NEM modeling, the scenario without planned infrastructure projects included a total of 257 routes to 12 ports of which 183 are road routes and 74 are multimodal routes. Also, the scenario considered 23 transshipment terminals. Seven corridors were composed of multimodal routes with railways, and three of them also had waterways (corridors to Santos/SP, Itacoatiara/AM, and Santarém/PA).

The scenario including the planned railways considered a total of 240 routes to the same previous 12 ports. In this scenario, more multimodal routes were chosen by the model (102), besides 138 road routes. A total of 48 terminals were included. Nine corridors were composed of multimodal routes with railways, and of these, only three corridors were composed of multimodal routes with waterways (the same corridors as in the ones without planned railways, but with more routes).

Due to the number of routes, Table 4 shows the average results of the analyzed corridors as an aggregation of routes to compose the 12 transport corridors to 12 export ports, by the modeling, the transport modes available or planned in each one, the average freight price, the average distance, and $\mathrm{CO}_{2}$ emissions.

Table 4. Transport modes, average distance, $\mathrm{CO}_{2}$ emissions, and freight price of each corridor.

\begin{tabular}{|c|c|c|c|c|c|c|c|}
\hline & Destination (Port) & COSTS & $\mathrm{CO}_{2}$ & Distance (km) & $\begin{array}{c}\text { Distance (km } \\
\text { of Road) }\end{array}$ & $\begin{array}{l}\text { Distance (km of } \\
\text { Rail and Water) }\end{array}$ & $\begin{array}{c}\text { Is There } \\
\text { Waterway? }\end{array}$ \\
\hline \multirow{12}{*}{$\begin{array}{c}\text { Current } \\
\text { Infrastructure }\end{array}$} & $\begin{array}{l}\text { São Francisco do } \\
\text { Sul (SC) }\end{array}$ & 85.98 & 15.651 & 424.133 & 424.133 & 0 & No \\
\hline & Belém (PA) & 164.71 & 38.256 & 1036.76 & 1036.76 & 0 & No \\
\hline & São Luís (MA) & 141.18 & 25.176 & 1103.331 & 520.993 & 582.338 & No \\
\hline & Santos (SP) & 144.62 & 33.334 & 1254.453 & 352.427 & 902.026 & Yes \\
\hline & Santarém (PA) & 200.98 & 47.472 & 1360.985 & 1245.566 & 115.419 & Yes \\
\hline & Paranaguá (PR) & 105.22 & 19.619 & 614.934 & 405.4781 & 209.456 & No \\
\hline & Rio Grande (RS) & 82.04 & 15.064 & 441.867 & 347.091 & 94.776 & No \\
\hline & Itacoatiara (AM) & 172.63 & 41.876 & 1880.917 & 728.354 & 1152.563 & Yes \\
\hline & Vitória (ES) & 142.45 & 27.877 & 1150.571 & 273.311 & 877.26 & No \\
\hline & Ilhéus (BA) & 133.35 & 29.251 & 792.712 & 792.712 & 0 & No \\
\hline & Fortaleza (CE) & 83.13 & 14.832 & 401.95 & 401.95 & 0 & No \\
\hline & Salvador (BA) & 143.58 & 32.19 & 872.365 & 872.365 & 0 & No \\
\hline \multirow{12}{*}{$\begin{array}{l}\text { Infrastructure } \\
\text { with planned } \\
\text { railways }\end{array}$} & $\begin{array}{l}\text { São Francisco do } \\
\text { Sul (SC) }\end{array}$ & 85.98 & 15.651 & 424.133 & 424.133 & 0 & No \\
\hline & Belém (PA) & 76.02 & 12.79 & 346.619 & 346.619 & 0 & No \\
\hline & São Luís (MA) & 129.69 & 21.634 & 1098.133 & 390.207 & 707.926 & No \\
\hline & Santos (SP) & 111.44 & 22.256 & 941.547 & 188.89 & 752.657 & Yes \\
\hline & Santarém (PA) & 107.67 & 28.269 & 1432.395 & 118.108 & 1314.287 & Yes \\
\hline & Paranaguá (PR) & 95.34 & 16.892 & 595.769 & 242.586 & 353.183 & No \\
\hline & Rio Grande (RS) & 74.81 & 12.88 & 470.816 & 143.983 & 326.833 & No \\
\hline & Itacoatiara (AM) & 151.64 & 36.36 & 1728.636 & 578.052 & 1150.584 & Yes \\
\hline & Vitória (ES) & 110.06 & 18.834 & 860.308 & 52.288 & 808.02 & No \\
\hline & Ilhéus (BA) & 104.37 & 19.178 & 913.024 & 26.897 & 886.127 & No \\
\hline & Fortaleza (CE) & 126.73 & 38.074 & 1044.02 & 143.982 & 900.038 & No \\
\hline & Salvador (BA) & 46.63 & 4.353 & 117.972 & 117.972 & 0 & No \\
\hline
\end{tabular}

Besides the information resultant of the NEM modeling presented in Table 4, the DEA also included the parameters DEPTH, STORAGE, PAVED, and ACCIDENTS presented in Table 3.

The results from the DEA modeling, i.e., the performance of the GTCs (DMUs), are presented in Table 5. The GTCs are ranked according to the final Composite Index (CI), with DMU22 with the best result, followed by DMU19. Table 5 also shows the intermediarysteps results for calculating the CI, i.e., the standard DEA Efficiency, the Inverted Efficiency (followed by its transformation), and the standardized average. 
Table 5. Efficiency Composite Index (CI) of the transport corridors.

\begin{tabular}{|c|c|c|c|c|c|c|c|}
\hline DMU & Port (State) & With Planned Railways & Efficiency & Inv.Efficiency & 1-Inv.Efficiency & Average & CI \\
\hline 22 & Ilhéus (BA) & Yes & 1.0000 & 0.1677 & 0.8323 & 0.9161 & 1.0000 \\
\hline 19 & Rio Grande (RS) & Yes & 1.0000 & 0.1761 & 0.8239 & 0.9119 & 0.9954 \\
\hline 17 & Santarém (PA) & Yes & 1.0000 & 0.2337 & 0.7663 & 0.8831 & 0.9640 \\
\hline 7 & Rio Grande (RS) & No & 0.7709 & 0.2288 & 0.7712 & 0.7711 & 0.8417 \\
\hline 18 & Paranaguá (PR) & Yes & 0.6061 & 0.2997 & 0.7003 & 0.6532 & 0.7130 \\
\hline 15 & São Luís (MA) & Yes & 0.4748 & 0.3652 & 0.6348 & 0.5548 & 0.6056 \\
\hline 6 & Paranaguá (PR) & No & 0.5153 & 0.4190 & 0.5810 & 0.5481 & 0.5983 \\
\hline 1 & São Francisco do Sul (SC) & No & 1.0000 & 1.0000 & 0.0000 & 0.5000 & 0.5458 \\
\hline 8 & Itacoatiara $(\mathrm{AM})$ & No & 1.0000 & 1.0000 & 0.0000 & 0.5000 & 0.5458 \\
\hline 13 & São Francisco do Sul (SC) & Yes & 1.0000 & 1.0000 & 0.0000 & 0.5000 & 0.5458 \\
\hline 20 & Itacoatiara (AM) & Yes & 1.0000 & 1.0000 & 0.0000 & 0.5000 & 0.5458 \\
\hline 24 & Salvador (BA) & Yes & 1.0000 & 1.0000 & 0.0000 & 0.5000 & 0.5458 \\
\hline 16 & Santos (SP) & Yes & 0.4636 & 0.4951 & 0.5049 & 0.4843 & 0.5286 \\
\hline 3 & São Luís (MA) & No & 0.3229 & 0.4517 & 0.5483 & 0.4356 & 0.4755 \\
\hline 5 & Santarém (PA) & No & 0.4384 & 1.0000 & 0.0000 & 0.2192 & 0.2393 \\
\hline 4 & Santos (SP) & No & 0.4231 & 1.0000 & 0.0000 & 0.2116 & 0.2309 \\
\hline 2 & Belém (PA) & No & 0.1468 & 1.0000 & 0.0000 & 0.0734 & 0.0801 \\
\hline 12 & Salvador (BA) & No & 0.1059 & 1.0000 & 0.0000 & 0.0530 & 0.0578 \\
\hline 14 & Belém (PA) & Yes & 0.1034 & 1.0000 & 0.0000 & 0.0517 & 0.0564 \\
\hline 9 & Vitória (ES) & No & 0.0835 & 1.0000 & 0.0000 & 0.0418 & 0.0456 \\
\hline 10 & Ilhéus (BA) & No & 0.0603 & 1.0000 & 0.0000 & 0.0301 & 0.0329 \\
\hline 21 & Vitória (ES) & Yes & 0.0198 & 1.0000 & 0.0000 & 0.0099 & 0.0108 \\
\hline 23 & Fortaleza (CE) & Yes & 0.0077 & 1.0000 & 0.0000 & 0.0039 & 0.0042 \\
\hline 11 & Fortaleza (CE) & No & 0.0005 & 1.0000 & 0.0000 & 0.0002 & 0.0003 \\
\hline
\end{tabular}

The benchmarks from the results of the DEA application can be seen in Table 6. It shows that the GTCs that serve as benchmarks to other corridors, due to similarities, are the following:

- $\quad$ Rio Grande (RS) is a benchmark to $2 / 3$ of the corridors.

- $\quad$ Santarém (PA) is a benchmark to almost $2 / 3$ of the corridors.

- Itacoatiara (AM), Ilhéus (BA), and Salvador (BA) are the benchmarks to at most 3 corridors each.

- $\quad$ São Francisco do Sul (SC) is a benchmark only to itself.

The other GTCs are inefficient corridors that need improvement to achieve the standard frontier. Tables 7 and 8 show the Goals and \% of variation to achieve the standard frontier. This is the number of changes necessary to turn the DMU efficient.

Table 6. Benchmarks in the Standard Frontier.

\begin{tabular}{|c|c|c|c|}
\hline Scenario & Destination (Ports) & DMU & Benchmark to DMU \\
\hline Current Infrastructure & $\begin{array}{c}\text { São Francisco do Sul (SC) } \\
\text { Belém (PA) } \\
\text { São Luís (MA) } \\
\text { Santos (SP) } \\
\text { Santarém (PA) } \\
\text { Paranaguá (PR) } \\
\text { Rio Grande (RS) } \\
\text { Itacoatiara (AM) } \\
\text { Vitória (ES) } \\
\text { Ilhéus (BA) } \\
\text { Fortaleza (CE) } \\
\text { Salvador (BA) }\end{array}$ & $\begin{array}{c}1 \\
2 \\
3 \\
4 \\
5 \\
6 \\
7 \\
8 \\
9 \\
10 \\
11 \\
12\end{array}$ & $\begin{array}{c}1 \text { (only the own DMU) } \\
0 \text { (inefficient, none) } \\
0 \text { (inefficient, none) } \\
0 \text { (inefficient, none) } \\
0 \text { (inefficient, none) } \\
0 \text { (inefficient, none) } \\
0 \text { (inefficient, none) } \\
8 \text { (only the own DMU) } \\
0 \text { (inefficient, none) } \\
0 \text { (inefficient, none) } \\
0 \text { (inefficient, none) } \\
0 \text { (inefficient, none) }\end{array}$ \\
\hline
\end{tabular}


Table 6. Cont.

\begin{tabular}{|c|c|c|c|}
\hline Scenario & Destination (Ports) & DMU & Benchmark to DMU \\
\hline \multirow[t]{12}{*}{$\begin{array}{l}\text { Infrastructure with } \\
\text { planned railways }\end{array}$} & São Francisco do Sul (SC) & 13 & 13 (only the own DMU) \\
\hline & Belém (PA) & 14 & 0 (inefficient, none) \\
\hline & São Luís (MA) & 15 & 0 (inefficient, none) \\
\hline & Santos (SP) & 16 & 0 (inefficient, none) \\
\hline & Santarém (PA) & 17 & $2,3,4,5,6,9,10,12,15,16,18,21,23$, and 17 (the own DMU) \\
\hline & Paranaguá (PR) & 18 & 0 (inefficient, none) \\
\hline & Rio Grande (RS) & 19 & $3,4,5,6,7,9,10,11,12,14,15,16,18,21,23$, and 19 (the own DMU) \\
\hline & Itacoatiara (AM) & 20 & 15 , and 20 (the own DMU) \\
\hline & Vitória (ES) & 21 & 0 (inefficient, none) \\
\hline & Ilhéus (BA) & 22 & 15,23 , and 22 (the own DMU) \\
\hline & Fortaleza (CE) & 23 & 0 (inefficient, none) \\
\hline & Salvador (BA) & 24 & 14 , and 24 (the own DMU) \\
\hline
\end{tabular}

The goals (standard frontier) from the results of the DEA application can be seen in Table 7. The efficient DMUs show the original measures as goals. Table 7 shows the goals of DMUs with planned railways (next infrastructure planned steps).

Table 7. Goals for decision-making units (DMUs) achieving the Standard Efficiency Frontier.

\begin{tabular}{|c|c|c|c|c|c|c|c|c|c|}
\hline & & & EXPORTS & DEPTH & STORAGE & PAVED & costs & $\mathrm{CO}_{2}$ & ACCIDENTS \\
\hline & Destination (Ports) & DMU & 01 & UI1 & UI2 & UI3 & I1 & UO1 & UO2 \\
\hline \multirow[t]{12}{*}{$\begin{array}{l}\text { Infrastructure } \\
\text { with planned } \\
\text { railways }\end{array}$} & $\begin{array}{l}\text { São Francisco do } \\
\text { Sul (SC) }\end{array}$ & 13 & 4422.16 & 14.00 & 861.11 & 2.23 & 85.98 & 15.65 & 59.90 \\
\hline & Belém (PA) & 14 & $12,927.29$ & 12.75 & 1855.42 & 1.99 & 74.51 & 12.79 & 6.48 \\
\hline & São Luís (MA) & 15 & $17,795.32$ & 18.00 & 1452.96 & 1.16 & 99.75 & 21.63 & 3.61 \\
\hline & Santos (SP) & 16 & $22,117.14$ & 16.29 & 2026.32 & 1.41 & 87.28 & 18.72 & 4.96 \\
\hline & Santarém (PA) & 17 & $36,921.74$ & 22.00 & 2277.60 & 0.44 & 107.67 & 28.27 & 2.62 \\
\hline & Paranaguá (PR) & 18 & $15,611.52$ & 13.78 & 1915.90 & 1.83 & 78.32 & 14.52 & 5.99 \\
\hline & Rio Grande (RS) & 19 & $13,065.19$ & 12.80 & 1872.68 & 2.00 & 74.81 & 12.88 & 6.40 \\
\hline & Itacoatiara (AM) & 20 & 1226.66 & 45.00 & 16.62 & 0.79 & 151.64 & 36.36 & 2.34 \\
\hline & Vitória (ES) & 21 & $22,295.29$ & 16.36 & 2029.34 & 1.40 & 87.52 & 18.83 & 4.94 \\
\hline & Ilhéus (BA) & 22 & 4146.67 & 9.30 & 243.85 & 1.11 & 104.37 & 19.18 & 0.41 \\
\hline & Fortaleza (CE) & 23 & $15,564.24$ & 13.73 & 1184.16 & 1.11 & 98.95 & 20.45 & 1.93 \\
\hline & Salvador (BA) & 24 & 0.05 & 8.00 & 237.31 & 1.10 & 46.63 & 4.35 & 13.90 \\
\hline
\end{tabular}

The $\%$ of variation to achieve the goals (standard frontier) from the results of the DEA application can be seen in Table 8 . The efficient DMUs shows $0 \%$ variation. Considering that the goal of DMUs with current infrastructure is to construct the planned railways, Table 8 shows the \% of variation to achieve the goals of DMUs with planned railways. The high values of \% for some DMUs as Vitória (ES) and Fortaleza (CE) are explained due to very low original values.

Table 8 is related to the slacks (used to calculate the percentages) and individual inefficiencies, but with values of changes expressed in percentages. Each percentage of variation of each measure to achieve the frontier is a reason for the inefficiency of each DMU. In other words, all measures are reasons for inefficiencies of at least one DMU. Table 9 shows the average contribution of the slacks to the inefficiencies, in general, for all corridors. 
Table 8. Percentage of Variation to Achieve the Goals (Standard Efficiency Frontier).

\begin{tabular}{|c|c|c|c|c|c|c|c|c|c|}
\hline & & & EXPORTS & DEPTH & STORAGE & PAVED & costs & $\mathrm{CO}_{2}$ & ACCIDENTS \\
\hline & Destination (Ports) & DMU & O1 & UI1 & UI2 & UI3 & I1 & UO1 & $\mathrm{UO2}$ \\
\hline \multirow[t]{12}{*}{$\begin{array}{c}\text { Infrastructure } \\
\text { with planned } \\
\text { railways }\end{array}$} & $\begin{array}{l}\text { São Francisco do } \\
\text { Sul (SC) }\end{array}$ & 13 & $0.00 \%$ & $0.00 \%$ & $0.00 \%$ & $0.00 \%$ & $0.00 \%$ & $0.00 \%$ & $0.00 \%$ \\
\hline & Belém (PA) & 14 & $821.12 \%$ & $27.49 \%$ & $1897.50 \%$ & $566.96 \%$ & $-1.98 \%$ & $0.00 \%$ & $-10.04 \%$ \\
\hline & São Luís (MA) & 15 & $134.63 \%$ & $0.00 \%$ & $189.87 \%$ & $53.11 \%$ & $-23.08 \%$ & $0.00 \%$ & $0.00 \%$ \\
\hline & Santos (SP) & 16 & $0.00 \%$ & $12.35 \%$ & $88.56 \%$ & $49.88 \%$ & $-21.68 \%$ & $-15.89 \%$ & $-70.91 \%$ \\
\hline & Santarém (PA) & 17 & $0.00 \%$ & $0.00 \%$ & $0.00 \%$ & $0.00 \%$ & $0.00 \%$ & $0.00 \%$ & $0.00 \%$ \\
\hline & Paranaguá (PR) & 18 & $0.00 \%$ & $8.52 \%$ & $36.93 \%$ & $3.63 \%$ & $-17.85 \%$ & $-14.03 \%$ & $-63.98 \%$ \\
\hline & Rio Grande (RS) & 19 & $0.00 \%$ & $0.00 \%$ & $0.00 \%$ & $0.00 \%$ & $0.00 \%$ & $0.00 \%$ & $0.00 \%$ \\
\hline & Itacoatiara (AM) & 20 & $0.00 \%$ & $0.00 \%$ & $0.00 \%$ & $0.00 \%$ & $0.00 \%$ & $0.00 \%$ & $0.00 \%$ \\
\hline & Vitória (ES) & 21 & $16,988.70 \%$ & $52.89 \%$ & $145.56 \%$ & $0.20 \%$ & $-20.48 \%$ & $0.00 \%$ & $-18.81 \%$ \\
\hline & Ilhéus (BA) & 22 & $0.00 \%$ & $0.00 \%$ & $0.00 \%$ & $0.00 \%$ & $0.00 \%$ & $0.00 \%$ & $0.00 \%$ \\
\hline & Fortaleza (CE) & 23 & $2778.43 \%$ & $37.34 \%$ & $36905.0 \%$ & $0.00 \%$ & $-21.92 \%$ & $-46.28 \%$ & $0.00 \%$ \\
\hline & Salvador (BA) & 24 & $0.00 \%$ & $0.00 \%$ & $0.00 \%$ & $0.00 \%$ & $0.00 \%$ & $0.00 \%$ & $0.00 \%$ \\
\hline
\end{tabular}

Comparing each relative slack to the sum of all relative slacks of each kind of factors separately (positive factors and outputs, or negative factors and inputs), it is possible to identify the contribution of each measure to the inefficiencies in Table 9.

Table 9. Contribution of the slacks to the inefficiencies.

\begin{tabular}{|c|c|c|c|c|c|c|c|}
\hline Scenario & EXPORTS & DEPTH & STORAGE & PAVED & costs & $\mathrm{CO}_{2}$ & ACCIDENTS \\
\hline $\begin{array}{l}\text { Average contribution of the slacks to the } \\
\text { inefficiencies (Current scenario) }\end{array}$ & $57.58 \%$ & $9.15 \%$ & $28.92 \%$ & $4.35 \%$ & $25.39 \%$ & $17.62 \%$ & $56.99 \%$ \\
\hline $\begin{array}{l}\text { Average contribution of the slacks to the } \\
\text { inefficiencies (Planned scenario) }\end{array}$ & $27.71 \%$ & $4.46 \%$ & $55.88 \%$ & $11.94 \%$ & $39.89 \%$ & $16.19 \%$ & $43.92 \%$ \\
\hline
\end{tabular}

In Table 9, it is possible to observe that the reason for inefficiencies changed from the current scenario to the planned scenario. In the first one, EXPORTS were responsible for more than $50 \%$ of inefficiencies compared to other positive factors, while ACCIDENTS were responsible for more than $50 \%$ of inefficiencies compared to other negative factors. In the second scenario, STORAGE was responsible for more than $50 \%$ of inefficiencies compared to other positive factors, while negative factors were more distributed than in the first scenario. Despite the changes in the reasons for inefficiencies due to the impact of the railways, comparing the NEM results to data, it is important to note that, from one scenario to another, COSTS and ACCIDENTS have the reduction potential between $26.88 \%$ and $29.23 \%$.

\section{Discussion}

\subsection{Discussion of Results without Planned Infrastructure Projects}

The performance analysis of the transportation corridors indicated that considering the scenarios without planned railways, the Rio Grande (RS) corridor is the most efficient (Table 3), followed by the Paranaguá (PR). The Rio Grande (RS) corridor has good measures, and it could be used for benchmarking best practices to others. The infrastructure stands out the most. It is possible to indicate its high grain storage capacity, high paved road density, the short distance roads leading to low average $\mathrm{CO}_{2}$ emission, and the lowest freight cost of the sample. In summary, it has very good measures. Paranaguá (PR) corridor has similar measures, but it has a worse capacity and roads (infrastructure and distance) than the Rio Grande (RS).

São Francisco do Sul (SC) and Itacoatiara (AM) were part of the double frontier (standard and inverted ones), indicating that they have simultaneously very good and very bad measures. An example of a good aspect is the low average freight cost of the São Francisco do Sul (SC) corridor, due to its short-distance routes. The results of the Itacoatiara (AM) corridor are explained by the low average $\mathrm{CO}_{2}$ emissions, due to the presence of 
important barge transportation on waterways alternative in this corridor, named Madeira River. As an example of bad aspects, we highlight the number of accidents per kilometer in the São Francisco do Sul (SC) corridor and high average freight cost in the Itacoatira (AM) corridor as well as its long-distance road routes. The second case is mainly explained due to the long road distances of transport flows among the origins and the barge road-river transshipment terminal located in Porto Velho (RO), before transporting cargo to Itacoatiara (AM) export port in this corridor.

The corridors of São Luís (MA), Santarém (PA), and Santos (SP) ports are middleranking ones. Despite the well-located Santos (SP) port accounting for the largest part of corn and soybean exports, being connected to the Tietê-Paraná waterways, a highquality road density, and high railway density, the Santos (SP) corridor attracts cargos from long-distance routes with poor infrastructure, low-quality roads, expensive freight price, and high $\mathrm{CO}_{2}$ emissions, resulting in inefficiency. The Santarém (PA) corridor is another corridor with long-distance waterways (the main one, Tapajós River, from Mato Grosso state to Pará state, and being connected to another waterway named Amazon River), but it also attracts cargos from long-distance routes with poor infrastructure, low-quality roads, expensive freight price, and high $\mathrm{CO}_{2}$ emissions, resulting in inefficiency.

Belém (PA), Salvador (BA), Vitória (ES), Ilhéus (BA), and Fortaleza (CE) corridors are among the last positions of the ranking. It is important to highlight that new railway infrastructures are planned to be constructed in the mid-term (for 2025 according to Planning and Logistics Company [36]) which could improve the performance of some corridors, particularly the Santarém (PA), Ilhéus (BA), and São Luís (MA).

In summary, the most efficient corridors were the ones from the South region of Brazil (Rio Grande (RS), Paranaguá (PR), and São Francisco do Sul (SC)), followed by those from the North and Northeast regions (Itacoatiara (AM), São Luís (MA), and Santarém (PA)).

\subsection{Discussion of Results with Planned Railways}

Among the corridors with planned railways, Ilhéus (BA), Santarém (PA), and São Luís (MA) corridors will be the ones most benefited by the projects. The Ilhéus (BA) corridor has the potential to increase its exports and decreasing the accidents per kilometer, because, based on the data, it is possible to observe that the railways induce fewer accidents per kilometer than roads, overtaking the Rio Grande (RS)'s position. The Santarém (PA) has a high potential for decreasing freight prices and $\mathrm{CO}_{2}$ emission, and, at the same time exporting large volumes, surpassing the Santos (SP) as the corridor that exports the most, and overtaking the Paranaguá (PR)'s position. Also, the modeling showed that the planned railways could increase the usage of the waterways in the routes of the Santarém (PA) corridor. The São Luís (MA) has the potential to increase the speed and is the corridor with more storage capacity, overtaking the São Francisco do Sul (SC)'s position. Therefore, the planned railways have the potential to increase the efficiency of corridors with ports from North-Northeast region states, instead of ports from the South in the current set up.

Among the corridors with waterways, the Santarém (PA) is the most benefited by the planned railways, being part of the standard frontier. Due to the location of the planned railways, it does not affect the Itacoatiara (AM) corridor directly, but it increases the efficiency of other corridors, in a way that the Itacoatiara (AM) drops positions in the ranking. And the Santos (SP) also increases its efficiency due to the planned railways, so it is not part of the inverted frontier anymore, but it is not enough to overtake other positions in the ranking, because, for example, the Ilhéus (BA) was more benefited than the Santos (SP).

In summary, the most efficient corridor was one from the Northeast region of Brazil, namely Ilhéus (BA), followed by an intercalation of corridors from South, North, and Northeast regions (Rio Grande (RS), Santarém (PA), Paranaguá (PR), São Luís (MA), São Francisco do Sul (SC), and Itacoatiara (AM)).

When comparing both scenarios, the first three positions are corridors with planned railways (Ilhéus (BA), Rio Grande (RS), and Santarém (PA)), and the third one also has a 
waterway. So, usually, the corridors from the scenario with planned railways are more efficient than the others. However, Rio Grande (RS), a corridor without planned infrastructure, is also top-ranked (fourth position). The middle-ranking corridors are mostly from the South and the corridors with waterways, but without planned railways, as São Francisco do Sul (SC), Santarém (PA), and Itacoatiara (AM).

Despite Santos (SP) being an important port, as a corridor, it is a middle-ranking DMU in both scenarios, due to the corridor's composition of long-distance routes from regions with less infrastructure.

\subsection{Theoretical and Practical Implications}

Firstly, the current results advanced the literature proposing a methodological approach that permits the efficiency relative comparison of GTCs, through a single index. Differently from previous efforts, this approach measures the corridor performance as a whole (instead of the individual routes) and it is focused on the destination port (instead of the origin). Besides, to the best of the authors' knowledge, the proposition of this dual-step approach with DEA and NEM models is a novelty for this application. The methodological approach has the advantages of being a single LCI (consequently, easy to understand), as well as the possibility of integrating financial and non-financial measures (as sustainable measures) and the reduction of subjectivisms (once the weights for index construction are automatically attributed).

Besides being a dual-step approach, it is also possible to compare the results from both models (NEM and DEA). Two kinds of correlations among NEM (total sum of distance, the sum of distance transporting by highway, the sum of distance transporting by waterway or railway, the sum of freight cost, and total the sum of $\mathrm{CO}_{2}$ emissions) and DEA results (efficiency Logistics Composite Index) were calculated. The first one was the Pearson's linear correlation coefficient. Only the sum of distance transporting by the highway had a significant $(p$-value $<0.10)$ correlation coefficient. The second one was Kendall's Tau ordinal correlation coefficient. Only the sum of $\mathrm{CO}_{2}$ emissions and the sum of freight cost had a significant ( $p$-value $<0.05$ ) correlation coefficient. All significant correlations, regardless of the method, presented a correlation coefficient between -0.3878 and -0.3817 , i.e., the LCI (DEA) and the NEM results had a medium to a low negative association. The higher the efficiency, the lower is the total freight cost, the total $\mathrm{CO}_{2}$ emissions, or the sum of distance transporting by highways. The freight cost per ton and $\mathrm{CO}_{2}$ emissions per ton also correlated near -0.35 , but were not significant.

Comparing the models in Equations (1)-(6), (12)-(20) to Vukic et al. (2020) [19], Pereira de Oliveira et al. (2020) [55], and Garcia et al. (2019) [8], it is possible to highlight the advantages of the proposed approach. These advantages result from the choice of slackbased measure (SBM), considering a double efficiency frontier (composite index tiebreaking method), assuming Variable Returns to Scale (VRS), and without orientation choice. For example, Vukic et al. (2020) [19] used a standard frontier, assuming CRS and an oriented model. Pereira de Oliveira et al. (2020) [55] applied the oriented BCC model and considered a double efficiency frontier (tiebreaking method) under VRS assumptions. Garcia et al. (2020) [8] applied the oriented BCC model, but also considered a double efficiency frontier (tiebreaking method) under VRS assumptions. It has already been pointed out that the VRS SBM model without orientation is more adequate for this kind of applications, once, in most situations, it is difficult to justify the choice of orientation and it cannot be assumed that there is a constant relationship between an increase (decrease) between all inputs and outputs [33].

Secondly, this paper also contributed to the proposition of a new combination of measures for widening the range of encompassed aspects. Comparing the measures in Table 3 with previous literature, it is possible to observe that Vukic et al. (2020) [19] computed the efficiency based on distance, transport time, transport costs per unit, and external costs per unit (including monetary valuation of GHG emissions as costs). The current paper excluded transport time and distance because they were highly correlated to 
$\mathrm{CO}_{2}$ emissions (environmental measure) and freight transport costs (economic measure). Besides, here, accidents were considered as a safety and social measure (in the sense of the lower, the better) and the current paper also considered the infrastructure of the ports and corridors. Pereira de Oliveira et al. (2020) [55] used safety measures (number of speeding per $\mathrm{km}$ and $\%$ of the speeding time), one economic measure (fuel consumption), and one operation measure ( $\%$ of operations in ecozone). Thus, despite being route-dependent measures, the current analysis focused on the corridors, while Pereira de Oliveira et al. (2019) [55] focused on the information from the Event Data Recorder (EDR) to evaluate the road freight transport. Garcia et al. (2019) [8] used the accident costs (safety, social, and economic measures), $\mathrm{CO}_{2}$ emissions (environmental measure), and the inverse of the freight cost per cargo carried (economic measure). The current paper considered $\mathrm{CO}_{2}$ emissions as well, but also the actual accidents (not its costs), freight cost, and cargo carried as independent measures. Besides, the current paper also considered the infrastructure of the ports and corridors (as structural, safety, and economic measures) because they can be designed to receive larger and more modern vessels, attract more cargo, store more grains, and improve the transportation flow.

Thirdly, besides the theoretical contribution, the results presented practical implications for decision- and policy-makers, especially because the application considered planned infrastructure projects. The results pointed out the benchmarks and the measures most contributed to their outstanding performance. This information has practical implications to the decision-makers about which GTCs to choose and which GTCs to prioritize management, new investments, and maintenance. Also, the results considering planned projects demonstrated that they have huge impact potential on corridors' performance. These results are relevant for policy-makers so that they can design investment and incentive strategies for efficient transportation.

Melo et al. (2018) [3] compared Brazilian and American routes (instead of corridors) and concluded that two routes in the USA performed the best, namely, a waterway followed by a railway. Among the worst routes were the ones using the only road (in both countries), followed by multimodal road-railway routes. However, they considered fewer railways because the planned infrastructure was not considered. In this regard, the current paper represented an advancement in the application, serving as a guideline for infrastructure investments and transportation policies.

\section{Conclusions}

This paper aimed to propose a dual-step procedure (NEM and DEA) to construct a multi-criteria composite index to evaluate the efficiency of Green Transport Corridors (GTCs), named Logistic Composite Index (LCI). The dual-step modeling with NEM and DEA is an important tool for assessing the sustainability performance (once it permits the integration of financial and non-financial measures), which is essential information for guiding operations, investments, and policies for the development of GTCs.

In summary, the results pointed out that the construction of the planned railways will have a direct impact on the efficiency of the current GTCs. The construction of the planned railways will highlight Ilhéus (BA) as the most efficient GTC in the future, followed by the Rio Grande (RS), and the Santarém (PA). They are the ones that serve as benchmarks for most of the analyzed corridors. The transport corridors which benefited the most from the planned railways were the ones with export ports from the North-Northeast region of the country, mainly the Ilhéus (BA), the Santarém (PA), and the São Luís (MA). On the other hand, the southern corridors of Rio Grande (RS), Paranaguá (PR), and São Francisco do Sul (SC) were not directly affected by the planned railways, and their positions were overtaken by the three corridors with export ports from the North-Northeast region. In this way, the results are useful for guiding decision-makers for efficient operations as well as guiding decision- and policy-makers about future investments in infrastructure and sustainability-based policies. 
For future research, it is recommended to construct an LCI to investigate the performance of all planned projects by state (or city). It is also suggested to investigate other contexts to apply the dual-step procedure, for example, using big data from Global Positioning Systems (GPS), and other jointly applied or integrated models, as DEA and Vehicle Routing Problems (DEA-VRP), to evaluate the impact of urban infrastructure projects (instead of the national integration ones) in urban routing.

Author Contributions: Conceptualization, P.N.A.J. and I.C.M.; Methodology, P.N.A.J. and J.E.H.B.; Software, P.N.A.J. and J.E.H.B.; Validation, P.N.A.J., I.C.M. and J.E.H.B.; Formal analysis, P.N.A.J. and I.C.M.; D.B.B. and J.E.H.B.; Investigation, P.N.A.J., I.C.M., D.B.B. and J.E.H.B.; Resources, J.V.C.-F., J.E.H.B., D.B.B. and P.N.A.J.; Data curation, P.N.A.J. and J.E.H.B.; Writing—original draft preparation, P.N.A.J. and I.C.M.; Writing—review and editing, I.C.M., P.N.A.J., D.B.B., J.E.H.B. and J.V.C.-F.; Visualization, I.C.M., P.N.A.J., J.E.H.B. and D.B.B.; Supervision, J.V.C.-F.; Project administration, J.V.C.-F.; Funding acquisition, J.V.C.-F. All authors have read and agreed to the published version of the manuscript.

Funding: This research was funded by São Paulo Research Foundation (FAPESP), grant number \# 2018/20436-1 and the APC was funded by São Paulo Research Foundation (FAPESP), grant number \# 2018/20436-1.

Institutional Review Board Statement: Not applicable.

Informed Consent Statement: Not applicable.

Data Availability Statement: Most of the data presented and analyzed in this study are publicly available datasets or openly available in a repository, and one source is available on request, as follows: (1) Governmental official sources provides information about exports and it can be found at <comexstat.mdic.gov.br/>. (2) Governmental official sources provides data about number of highway accidents at <cnt.org.br/painel-acidente>. (3) Governmental official sources provides data about number of railway accidents at <portal.antt.gov.br/anuario-do-setor-ferroviario>. (4) A study with data about number of waterway accidents can be found in the following link: ezute.org. br/wp-content/uploads/2016/11/SAutores-Relatorio-Estudo-da-Hidrovia-do-Madeira.pdf. (5) Governmental official sources provides data about port depth can be found at <observatorioantaq. info/index.php/category/portos-brasileiros>. (6) Governmental official sources provides data about storage at <ibge.gov.br/estatisticas/economicas/agricultura-e-pecuaria/9199-pesquisa-de-estoques. $h t m l ?=\& t=0-q u e-e>$. (7) Governmental official sources provides data about paved highway at $<w w w . g o v . b r / d n i t / p t-b r / a s s u n t o s / a t l a s-e-m a p a s / p n v-e-s n v>$. (8) Information about the $\mathrm{CO}_{2}$ emission can be found in the following papers: [3] < doi.org/10.1108/BIJ-11-2016-0175>, and [12] $<$ doi.org/10.1016/j.tranpol.2020.03.011>. (9) The freight cost data are available on request from the ESALQ-LOG group at <esalqlog.esalq.usp.br> or <sifreca.esalq.usp.br>. (10) Results per route can be found at <github.com/pjnocera/NEM-results-and-data-for-DEA---JMSE106605 > or <http: //doi.org/10.5281/zenodo.4542482>.

Acknowledgments: The authors would like to thank the members of the Group of Research and Extension in Agroindustrial Logistics (ESALQ-LOG) for the support.

Conflicts of Interest: The authors declare no conflict of interest. The funders had no role in the design of the study; in the collection, analyses, or interpretation of data; in the writing of the manuscript, or in the decision to publish the results.

\section{References}

1. Panagakos, G. Green corridors basics. In Green Transportation Logistics: The Quest for Win-Win Solutions; Springer International Publishing: Cham, Switzerland, 2015; pp. 81-121, ISBN 9783319171753.

2. Schröder, M.; Prause, G. Risk Management for Green Transport Corridors. J. Secur. Sustain. Issues 2015, 5, 229-239. [CrossRef]

3. Melo, I.C.; Alves Junior, P.N.; Perico, A.E.; Guzman, M.G.; Do Nascimento Rebelatto, D.A. Benchmarking freight transportation corridors and routes with data envelopment analysis (DEA). Benchmark. Int. J. 2018, 25, 713-742. [CrossRef]

4. World Bank. Logistics Performance Index (LPI). 2019. Available online: https://lpi.worldbank.org/international/scorecard (accessed on 13 August 2019).

5. GreCOR. Final Report on Inventory and Analysis for Green Corridor Development Title Final Report on Inventory and Analysis for Green Corridor Development. 2015. Available online: http:/ / www.hs-emden-leer.de/forschung- (accessed on 27 February 2020). 
6. Hunke, K.; Prause, G. Management of green corridor performance. Transp. Telecommun. 2013, 14, 292-299. [CrossRef]

7. Prause, G.; Schröder, M. KPI building blocks for successful green transport corridor implementation. Transp. Telecommun. 2015, 16, 277-287. [CrossRef]

8. Garcia, B.T.; Lopes, D.M.; Leal Junior, I.C.; Amorim, J.C.; Da Silva, M.A.; Guimarães, V.D. Analysis of the Performance of Transporting Soybeans from Mato Grosso for Export: A Case Study of the Tapajós-Teles Pires Waterway. Sustainability 2019, 11, 6124. [CrossRef]

9. Wardrop, J.G. Road paper. some theoretical aspects of road traffic research. Proc. Inst. Civ. Eng. 1952, 1, 325-362. [CrossRef]

10. Florian, M.; Hearn, D. Network Equilibrium and Pricing. In Handbook of Transportation Science; Kluwer Academic Publishers: Boston, MA, USA, 2003; pp. 373-411.

11. Friesz, T.L.; Harker, P.T. Multicriteria spatial price equilibrium network design: Theory and computational results. Transp. Res. Part B Methodol. 1983, 17, 411-426. [CrossRef]

12. Holler Branco, J.E.; Bartholomeu, D.B.; Alves Junior, P.N.; Caixeta Filho, J.V. Evaluation of the economic and environmental impacts from the addition of new railways to the brazilian's transportation network: An application of a network equilibrium model. Transp. Policy 2020. [CrossRef]

13. Zhou, M.; Duan, Y.; Yang, W.; Pan, Y.; Zhou, M. Capacitated multi-modal network flow models for minimizing total operational cost and CO2e emission. Comput. Ind. Eng. 2018, 126, 361-377. [CrossRef]

14. Wang, G.; Chen, A.; Kitthamkesorn, S.; Ryu, S.; Qi, H.; Song, Z.; Song, J. A multi-modal network equilibrium model with captive mode choice and path size logit route choice. Transp. Res. Part A Policy Pract. 2020, 136, 293-317. [CrossRef]

15. Branco, J.E.; Bartholomeu, D.B.; Vettorazzi, A.C. Avaliação das emissões de co2 na etapa de transporte do etanol: Aplicação de um modelo de otimização. Transportes 2020, 28, 63-80. [CrossRef]

16. Mahmoudi, R.; Emrouznejad, A.; Shetab-Boushehri, S.-N.; Hejazi, S.R. The origins, development and future directions of data envelopment analysis approach in transportation systems. Socioecon. Plan. Sci. 2020, 69, 100672. [CrossRef]

17. Huang, T.; Chen, Z.; Wang, S.; Jiang, D. Efficiency Evaluation of Key Ports along the 21st-Century Maritime Silk Road Based on the DEA-SCOR Model. Marit. Policy Manag. 2020, 1-13. [CrossRef]

18. Martin, J.C.; Gutierrez, J.; Roman, C. Data Envelopment Analysis (DEA) index to measure the accessibility impacts of new infrastructure investments: The case of the high-speed train corridor Madrid-Barcelona-French border. Reg. Stud. 2004, 38, 697-712. [CrossRef]

19. Vukić, L.; Poletan Jugović, T.; Guidi, G.; Oblak, R. Model of Determining the Optimal, Green Transport Route among Alternatives: Data Envelopment Analysis Settings. J. Mar. Sci. Eng. 2020, 8, 735. [CrossRef]

20. Mirza, F.M.; Fatima, N.; Ullah, K. Impact of China-Pakistan economic corridor on Pakistan's future energy consumption and energy saving potential: Evidence from sectoral time series analysis. Energy Strateg. Rev. 2019, 25, 34-46. [CrossRef]

21. Wiegmans, B.; Champagne-Gelinas, A.; Duchesne, S.; Slack, B.; Witte, P. Rail and road freight transport network efficiency of Canada, member states of the EU, and the USA. Res. Transp. Bus. Manag. 2018, 28, 54-65. [CrossRef]

22. Fanou, E.H.; Wang, X. Assessment of transit transport corridor efficiency of landlocked African countries using data envelopment analysis. S. Afr. J. Sci. 2018, 114. [CrossRef]

23. Santos, A.B.; Sproesser, R.L.; Batalha, M.O.; Campeão, P.; Pereira, M.W. Are the grain intermodal terminals in Brazil's Northeastern region efficient? Custo e Agronegócios Online 2016, 12, 64-83.

24. Swami, M.; Parida, M. Comparative Appraisal of Metro Stations in Delhi Using Data Envelopment Analysis in a Multimodal Context. J. Public Transp. 2015, 18, 29-51. [CrossRef]

25. Yushimito, W.F.; Alves, P.N., Jr.; Canessa, E.; De Mateo, F. Relating Efficiency with Service Compliance Indices in Public Transportation Using Slack-based Measure Data Envelopment Analysis and Shadow Prices. Promet Traffic Transp. 2018, 30, 661-670. [CrossRef]

26. De Oliveira, A.E.; Cicolin, L.D. Evaluating the logistics performance of Brazil's corn exports: A proposal of indicators. Afr. J. Agric. Res. 2016, 11, 693-700. [CrossRef]

27. Dyckhoff, H.; Souren, R. Data Envelopment Methodology of Performance Evaluation. In Performance Evaluation. Foundations and Challenges; Springer International Publishing: Cham, Switzerland, 2020; pp. 47-82.

28. Dyson, R.G.; Allen, R.; Camanho, A.S.; Podinovski, V.V.; Sarrico, C.S.; Shale, E.A. Pitfalls and protocols in DEA. Eur. J. Oper. Res. 2001, 132, 245-259. [CrossRef]

29. Tone, K. A slacks-based measure of efficiency in data envelopment analysis. Eur. J. Oper. Res. 2001, 130, 498-509. [CrossRef]

30. Rentizelas, A.; Melo, I.C.; Alves Junior, P.N.; Campoli, J.S.; Do Nascimento Rebelatto, D.A. Multi-criteria efficiency assessment of international biomass supply chain pathways using Data Envelopment Analysis. J. Clean. Prod. 2019, 237, 117690. [CrossRef]

31. Mariano, E.B.; Gobbo, J.A.; De Castro Camioto, F.; Do Nascimento Rebelatto, D.A. $\mathrm{CO}_{2}$ emissions and logistics performance: A composite index proposal. J. Clean. Prod. 2017, 163, 166-178. [CrossRef]

32. Melo, I.C.; Alves Junior, P.N.; Pera, T.G.; Caixeta-Filho, J.V.; Do Nascimento Rebelatto, D.A. Framework for logistics performance index construction using DEA: An application for soybean haulage in Brazil. In Proceedings of the World Conference on Transportation Research, Mumbai, India, 26-31 May 2019.

33. Cook, W.D.; Tone, K.; Zhu, J. Data envelopment analysis: Prior to choosing a model. Omega 2014, 44, 1-4. [CrossRef]

34. Banker, R.; Cooper, A.; Charnes, W. Some Models for Estimating Technical and Scale Inefficiencies in Data Envelopment Analysis. Manag. Sci. 1984, 30, 1078-1092. [CrossRef] 
35. Charnes, A.; Cooper, W.W.; Rhodes, E. Measuring the efficiency of decision making units. Eur. J. Oper. Res. 1978, 2, 429-444. [CrossRef]

36. Cooper, W.W.; Seiford, L.M.; Tone, K. Data Envelopment Analysis: A Comprehensive Text with Models, Applications, References and DEA-Solver Software; Springer: New York, NY, USA, 2007.

37. Golany, B.; Roll, Y. An application procedure for DEA. Omega 1989, 17, 237-250. [CrossRef]

38. Leta, F.R.; Soares de Mello, J.C.; Gomes, E.G.; Meza, L.A. Métodos de melhora de ordenação em DEA aplicados à avaliação estática de tornos mecânicos. Investig. Oper. 2005, 25, 229-242.

39. Liu, W.; Zhou, Z.; Ma, C.; Liu, D.; Shen, W. Two-stage DEA models with undesirable input-intermediate-outputs. Omega 2015, 56, 74-87. [CrossRef]

40. Ministry of Infrastructure. Maps and Bases of Transport Modes [Mapas e Bases dos Modos de Transportes]. 2020. Available online: https:/ / www.gov.br/infraestrutura/pt-br/assuntos/dados-de-transportes/bit/bitmodosmapas\#mapport (accessed on 14 February 2021).

41. Planning and Logistics Company [Empresa de Planejamento e Logística] Downloads. 2020. Available online: https:/ /www.ontl. epl.gov.br/downloads (accessed on 14 February 2021).

42. Ministry of Infrastructure. Railways [Ferrovias]. 2020. Available online: https://issuu.com/bit_mtpa/docs/ferrovias_fichas (accessed on 14 February 2021).

43. Ministry of Industry. Exterior Commerce and Services ComexStat. 2018. Available online: http://comexstat.mdic.gov.br/ (accessed on 14 February 2021).

44. ANTAQ-National Waterway Transportation Agency, Information about Brazilian ports. 2019. Available online: http:// observatorioantaq.info/index.php/category/portos-brasileiros (accessed on 7 April 2019).

45. IBGE. Pesquisa de Estoques I IBGE. 2019. Available online: https://www.ibge.gov.br/estatisticas/economicas/agricultura-epecuaria/9199-pesquisa-de-estoques.html?=\&t=0-que-e (accessed on 11 March 2020).

46. ANTT. ANTT-National Land Transportation Agency. 2020. Available online: http://www.antt.gov.br/ (accessed on 30 August 2019).

47. DNIT. PNV and SNV. 2020. Available online: https://www.gov.br/dnit/pt-br/assuntos/atlas-e-mapas/pnv-e-snv (accessed on 18 September 2019).

48. ESALQ-LOG. Grupo de Pesquisa e Extensão em Logística Agroindustrial. 2018. Available online: http:/ / esalqlog.esalq.usp.br/ (accessed on 5 July 2018).

49. CNT-National Transport Confederation [Confederação Nacional de Transporte], Accidents Pannel [Painel de Acidentes]. 2019. Available online: https:/ / www.cnt.org.br/painel-acidente (accessed on 14 February 2021).

50. ANTT_Land National Transportation Agency [Agência Nacional de Transporte Terrestre], Railway Sector Yearbook [Anuário do Setor Ferroviário]. 2020. Available online: https:/ / portal.antt.gov.br/anuario-do-setor-ferroviario (accessed on 14 February 2021).

51. Naval War School [Escola Naval de Guerra] and Foundation EZUTE [Fundação EZUTE], Prospecting for Futures: Madeira Waterway Study [Prospeç̧ão de Futuros: Estudo da Hidrovia do Madeira]. 2016. Available online: https:/ / ezute.org.br/wpcontent/uploads/2016/11/SAutores-Relatorio-Estudo-da-Hidrovia-do-Madeira.pdf (accessed on 14 February 2021).

52. ANTAQ - National Waterway Transportation Agency, Hidroanel Metropolitano \& Dinamização da Hidrovia Tietê - Paraná. 2019. Available online: http://web.antaq.gov.br/portalv3/pdf/Palestras/SeminarioBrasilHolanda/Painel1 /PalestraFredericoBussinger.pdf (accessed on 7 April 2019).

53. ANTT-Land National Transportation Agency [Agência Nacional de Transporte Terrestre], Declaration of Railway Network [Declaração de Rede]. 2020. Available online: https:/ / portal.antt.gov.br/declaracao-de-rede-2020 (accessed on 14 February 2021).

54. Seiford, L.M.; Zhu, J. Modeling undesirable factors in efficiency evaluation. Eur. J. Oper. Res. 2002, 142, 16-20. [CrossRef]

55. Pereira de Oliveira, L.; Jiménez Alonso, F.; Vieira da Silva, M.A.; Tostes de Gomes Garcia, B.; Messias Lopes, D.M. Analysis of the Influence of Training and Feedback Based on Event Data Recorder Information to Improve Safety, Operational and Economic Performance of Road Freight Transport in Brazil. Sustainability 2020, 12, 8139. [CrossRef] 